\title{
In silico prediction of the effects of mutations in the human triose phosphate isomerase gene: towards a predictive framework for TPI deficiency
}

Conor Oliver ${ }^{1,2}$ and David J. Timson ${ }^{1,3^{*}}$

${ }^{1}$ School of Biological Sciences and 2School of Medicine, Dentistry and Biomedical Sciences, Queen's University Belfast, Medical Biology Building, 97 Lisburn Road, Belfast, BT9 7BL. UK.

${ }^{3}$ School of Pharmacy and Biomolecular Sciences, University of Brighton, Huxley Building, Lewes Road, Brighton, BN2 4GJ. UK.

* Author to whom correspondence should be addressed.

School of Pharmacy and Biomolecular Sciences, University of Brighton, Huxley Building, Lewes Road, Brighton, BN2 4GJ. UK.

Telephone $\quad+44(0) 1273641623$

Fax $\quad+44(0) 1273642090$

Email d.timson@brighton.ac.uk 


\begin{abstract}
Triose phosphate isomerase (TPI) deficiency is a rare, but highly debilitating, inherited metabolic disease. Almost all patients suffer severe neurological effects and the most severely affected are unlikely to live beyond early childhood. Here, we describe an in silico study into well-characterised variants which are associated with the disease alongside an investigation into 79 currently uncharacterised TPI variants which are known to occur in the human population. The majority of the disease-associated mutations affected amino acid residues close to the dimer interface or the active site. However, the location of the altered amino acid residue did not predict the severity of the resulting disease. Prediction of the effect on protein stability using a range of different programs suggested a relationship between the degree of instability caused by the sequence variation and the severity of the resulting disease. Disease-associated variations tended to affect well-conserved residues in the protein's sequence. However, the degree of conservation of the residue was not predictive of disease severity. The majority of the 79 uncharacterised variants are potentially associated with disease since they were predicted to destabilise the protein and often occur in wellconserved residues. We predict that individuals homozygous for the corresponding mutations would be likely to suffer from TPI deficiency.
\end{abstract}

Keywords: TPI deficiency; in silico prediction; inherited metabolic disease; protein stability; diseaseassociated variant; glycolytic enzyme 


\section{Introduction}

Triose phosphate isomerse (TPI; EC 5.3.1.1) catalyses a key step in the glycolytic pathway, namely the interconversion of dihydroxyacetone phosphate (DHAP) and glyceraldehyde 3-phosphate (GLA3P), the two products of the splitting of fructose 1,6-bisphosphate catalysed by adolase (EC 4.1.2.13). This step is necessary, since only GLA3P can be processed by the subsequent reactions in the pathway. Thus, TPI ensures that the three carbon atoms in DHAP can be utilised in glycolysis and subsequent pathways. In addition to this metabolic role it has been proposed that TPI also functions in sperm-egg recognition in mammals and may have non-metabolic roles in nerve cells (Auer et al., 2004; Petit et al., 2014; Roland et al., 2013; Roland et al., 2016).

TPI is an example of a 'kinetically perfect' enzyme since its activity is limited only by the rates of diffusion of substrate and product molecules (Stroppolo et al., 2001). In humans, TPI is encoded by a single gene (TPI1) located at chromosome 12p13 and is expressed in all tissues. TPI is expressed in almost every organism from bacteria to humans and its amino acid sequence is highly conserved. In healthy individuals, this enzyme exists as a stable homodimer of two $27 \mathrm{kDa}$ subunits each of which consists of 248 amino acids. Although each monomer has a full set of catalytic residues, TPI is only active its dimeric form (De La Mora-De La Mora et al., 2013). TPI monomers have been shown to be thermodynamically unstable, demonstrating the crucial role of the dimeric form in both enzyme stability and catalytic function (Mainfroid et al., 1996).

First described in 1964, TPI deficiency (OMIN \#615512) is a rare, multisystem disorder with autosomal recessive inheritance and is the most severe of the known glycolytic enzymopathies. However, clinical presentation varies between patients (Schneider et al., 1964; Schneider et al., 1965). The most common phenotypes include nonspherocytic haemolytic anaemia (often presenting as neonatal jaundice) and, in all but two reported cases, progressive neuromuscular impairment that almost inevitably culminates in the death of the patient in infancy or early childhood (Sarper et al., 2013). Other common phenotypes include cardiomyopathy and an increased susceptibility to infection (Schneider, 2000). These physical characteristics are generally accompanied by a decrease in enzyme activity in all tissues and an increase in the levels of DHAP in erythrocytes (Orosz et al., 2006). Although prenatal detection has become available, there has been no effective therapy developed for TPI deficiency and treatment is generally only supportive (Pekrun et al., 1995; Poinsot et al., 1986; Rosa et al., 1986). A number of studies have reported some limited success with enzyme replacement therapy (Ationu and Humphries, 1998; Ationu et al., 1997; Ationu et al., 1999a; Ationu et al., 1999b).

In total, fewer than 50 cases of TPI deficiency have been reported in the literature. Intriguingly, population studies have revealed a surprisingly high frequency of healthy heterozygote carriers - much 
higher than would be suggested by the comparative scarcity of TPI deficiency cases (Eber et al., 1984). The frequency of heterozygosity has been estimated at 9 in 1,713 among Caucasians and 7 in 168 among African Americans (Watanabe et al., 1996). One possible explanation for this apparent discrepancy is that many foetuses homozygous or compound heterozygous for TPI deficiency mutations often die in utero. This is supported by studies performed on mice that demonstrated that mutations which resulted in TPI variants which were catalytically inactive (null alleles) caused early prenatal lethality in homozygotes for such mutations (Merkle and Pretsch, 1989). This theory is further substantiated by anecdotal evidence that mothers of TPI deficiency cases often have a personal and/or family history of frequent miscarriages (Valentin et al., 2000). Alternatively, it may be the case that heterozygotes are less fertile than wild-type homozygotes. Some evidence suggests that the tail regions of human spermatozoa are dependent on glycolysis for the majority of their ATP generation (du Plessis et al., 2015). It is also possible that there are phenotypes associated with homozygosity which are not currently known to be associated with TPI deficiency.

The underlying molecular basis of TPI deficiency is still a matter of some debate. Early propositions that the reduced TPI activity would lead to a reduction in the rate of glycolysis, and subsequently the rate of ATP synthesis, have been largely disproven due to the relative paucity of metabolic abnormalities other than a markedly increased DHAP level (Hollan et al., 1993; Orosz et al., 1996; Schneider, 2000). It was postulated that when DHAP accumulated to such high levels as a result of decreased TPI activity, it would inhibit the action of myo-inositol-3-phosphate synthase, which would contribute to the clinical manifestations of this disease (Shi et al., 2005). Although there has been very little indication that DHAP itself is toxic, it does decompose non-enzymatically to form methylglyoxal, a potent glycating agent that can modify proteins and DNA to form advanced glycation end products (AGEs) (Li et al., 2008). The accumulation of these AGEs can lead to oxidative stress, DNA damage and, consequently, to apoptosis. Indeed methylglyoxal has already been shown to be neurotoxic and therefore may contribute to the neurological impairment seen in many TPI deficiency patients (Ahmed et al., 2003; de Arriba et al., 2006; de Arriba et al., 2007). Abnormal dimerisation behaviour of diseaseassociated TPI variants has been suggested as a potential contributing factor in the pathogenesis of TPI deficiency (Ralser et al., 2006; Rodriguez-Almazan et al., 2008; Roland et al., 2016). In recent years the suggestion has arisen that this may be as a consequence of the formation of toxic protein aggregates in the brain due to the misfolding of the variant TPI (Olah et al., 2002; Olah et al., 2005)). This "conformational disease" hypothesis of TPI deficiency is supported by a growing body of evidence. A bioinformatics investigation was undertaken to better understand the functional and structural contribution of molecular alterations in TPI and how these correlate to the associated severity. The results of these investigations were then compared against the relative severity of their associated 


\section{Materials and Methods}

Datasets

The identification and gathering of information on the known, investigated missense mutations associated with TPI deficiency were carried out by searching the literature on the NCBI PubMed database (http://www.ncbi.nlm.nih.gov/pubmed). Where available, the associated clinical symptoms seen in the relevant patient(s), along with pertinent biochemical results, including TPI activity and DHAP levels measured in red blood cells, and genetic background of the propositus was recorded for each mutant (Table 1; Supplementary Table S1; see also Table 1 in (Orosz et al., 2006)). Reported missense mutants from exome sequencing that had not been previously investigated were identified from the NCBI dbSNP database (http://www.ncbi.nlm.nih.gov/SNP/).

\section{Structural analysis}

Structural studies were based on the crystal structure of human TPI (PDB: 4POC; (Roland et al., 2015; Roland et al., 2013)) obtained from the RCSB protein data bank (http://www.rcsb.org/pdb/home/home.do)(Berman et al., 2002; Berman et al., 2000). Secondary structural elements were defined according to Supplementary Table S2. The structures were visualised using PyMol (http://www.pymol.org) and were computationally solvated and energy minimised using YASARA (http://www.yasara.org) (Krieger et al., 2009). Sequence variations were 


\section{Prediction of biochemical effects of each missense mutation on TPI deficiency}

Prediction of the effect of individual mutations on protein stability and/or the likelihood of it leading to disease was carried out using a variety of web servers which are freely available. I-mutant 3.0 (http://gpcr2.biocomp.unibo.it/cgi/predictors/I-Mutant3.0/I-Mutant3.0.cgi) reports the predicted effect of a specific mutation on protein stability using either a structure file ( $p d b$ file) or the amino acid sequence (Capriotti et al., 2005; Capriotti et al., 2008). It also reports the relative solvent accessibility value and the reliability index of the reported result from 1 to 10 with 10 being very reliable and 1 being very unreliable. $\mathrm{A} \mathrm{pH}$ of 7.5 and a temperature of $37^{\circ} \mathrm{C}$ were used in order to replicate human cellular conditions. The mutation Cutoff Scanning Matrix (mCSM) (http://bleoberis.bioc.cam.ac.uk/mcsm/) (Pires et al., 2014) reports the protein stability change $(\Delta \Delta \mathrm{G})$ in $\mathrm{kcal}^{\mathrm{mol}}{ }^{-1}$ for each mutation on one chain of the protein (in this case chain A) using the energy minimised wildtype pdb file. The SDM server (http://mordred.bioc.cam.ac.uk/ sdm/sdm.php) reports the pseudo $\Delta \Delta \mathrm{G}$ in $\mathrm{kcal}^{\mathrm{mol}}{ }^{-1}$, that predicts its effect on protein stability ranging from highly stabilising to neutral to highly destabilising and a number of degrees in between as well as whether or not the mutation is predicted to be disease-associated (Worth et al., 2011). A meta-predictor of disease causing variants, Meta-SNP (Capriotti et al., 2013) (http://snps.biofold.org/meta-snp/) reports the results from a number of prediction servers. PANTHER, PhD-SNP and SNAP all report a normalised value between zero and one and if this value is greater than 0.5 the mutation is predicted to cause 
disease. SIFT reports a positive value which, if greater than 0.05 , is predictive of a mutation being neutral. From these values, Meta-SNP then calculates a meta-result between zero and one which, again, if greater than 0.5 predicts that the mutation will be disease associated. Predict-SNP 1.0 (Bendl et al., 2014) (http://loschmidt.chemi.muni.cz/predictsnp/) reports the qualitative results (deleterious or neutral), along with the percentage predicted accuracy of the result, for eight prediction tools MAPP (Stone and Sidow, 2005), PhD-SNP (Capriotti et al., 2006), PolyPhen-1, PolyPhen-2 (Adzhubei et al., 2010), SIFT (Kumar et al., 2009), SNAP (Bromberg and Rost, 2007), nsSNP-Analyser (Bao et al., 2005) and PANTHER (Thomas et al., 2003) - and then combines the results for the six best performing tools (the former six in this list) into a consensus classifier in the form of Predict-SNP. Using sequence information only, MUpro (http://mupro.proteomics.ics.uci.edu/) (Cheng et al., 2006) qualitatively predicts protein stability changes (Increase/Decrease) for single amino acid mutations using two methods - support vector machines and neural networks - along with the associated confidence score. The Cologne University protein stability analysis tool (CUPSAT) (http://cupsat.tu-bs.de/) reports the predicted $\Delta \Delta G$ for each mutation affecting one chain as well as the predicted effect of the mutation on overall stability (stabilising/destabilising/no change) and torsion (favourable/unfavourable/no change) (Parthiban et al., 2006). BeAtMuSiC (http://babylone.ulb.ac.be/beatmusic/) evaluates the impact of mutations on protein-protein binding affinity based on protein structure and also reports the solvent accessibility in complex (Dehouck et al., 2013). nsSNPAnalyser (http://snpanalyzer.uthsc.edu) also qualitatively predicts if a mutation is disease-associated or neutral (Bao et al., 2005). TANGO predicts the likelihood of a protein to aggregate and reports this prediction using a variety of scores (Fernandez-Escamilla et al., 2004b). The value deemed most relevant to this study was the AGG Score, which represents the tendency for $\beta$-sheet aggregation. A summary spreadsheet of the key findings from each server for each disease-associated variant is provided as Supplementary Table S1.

The aggregation potential of the wild-type and variant proteins was predicted using several servers. TANGO (http://tango.crg.es/) (Fernandez-Escamilla et al., 2004a; Linding et al., 2004; Rousseau et al., 2006) determines an aggregation score based on the protein sequence, with higher scores indicating a greater tendency for aggregation. This program also returns a prediction of the likelihood of forming amyloid. Predictions were carried out with unmodified N- and C-termini, at $\mathrm{pH} 7.5$, temperature of $298 \mathrm{~K}$, ionic strength of $150 \mathrm{mM}$ and a protein concentration of $10 \mu \mathrm{M}$. CamSol (http://wwwmvsoftware.ch.cam.ac.uk/index.php/camsolintrinsic) also makes predictions about the likely soluble or aggregated state of a protein, returning an intrinsic solubility score; the higher this score, the more soluble the protein (Sormanni et al., 2015). Zyggregator (http://wwwmvsoftware.ch.cam.ac.uk/index.php/zyggregator) estimates the sequence-dependent properties of 
proteins returning a score; a high score indicates increased, predicted amyloid propensity (Tartaglia et al., 2008). Both CamSol and Zyggregator were run at pH 7. AGGRESCAN (http://bioinf.uab.es/aggrescan/) identifies the number of aggregation "hotspots" in proteins and also returns an "area above the threshold" with higher values suggesting a greater likelihood of aggregation (Conchillo-Sole et al., 2007). FoldAmyloid (http://bioinfo.protres.ru/fold-amyloid/) predicts the number of regions in a protein with amyloid-forming potential and also returns an overall score for the protein (Garbuzynskiy et al., 2010). It was deployed using the default parameters, i.e. an averaging frame of five residues and a threshold score of 21.4. The scores for each disease-associated variant from the aggregation predictions were normalised against the wild-type score such that a number higher than 1.0 indicated increased likelihood of aggregation. The mean, normalised score was then calculated for each variant and compared by ANOVA (using GraphPad Prism 6.0). A similar treatment was used with the amyloid propensity scores.

\section{Results}

TPI deficiency variants can be arranged into four groups depending on severity of their associated clinical patterns

Two variants (Ile170Val and Phe240Leu) were classified as "pathological (less severe)" since these were the only two which are associated with patients who did not develop neurological symptoms the main cause of death in TPI deficiency (Arya et al., 1997; Chang et al., 1993; Schneider, 2000; Valentin et al., 2000). Phe240Leu is a somewhat unusual case because two brothers were reported to have TPI deficiency resulting from this variant. Although one brother did display some neuromuscular impairment, because the impairment was relatively minor and did not develop until the age of 12 (relatively late compared to more 'stereotypical' forms of the disease), as well as the fact that both brothers have survived well into adulthood (Chang et al., 1993), this mutation was classified as "pathological (less severe)".

Two variants (Glu104Asp and Phe240Ser) were classified as "pathological (severe)" due to the severity of the associated symptoms. Case reports for Glu104Asp homozygote patients, as well as the one case report for the Phe240Ser/Glu104Asp compound heterozygote, have described haemolytic anaemia, early neuromuscular impairment (often within the first six months) and increased susceptibility to infection. Patients often die in infancy or early childhood and no case has survived past the age of six (Fermo et al., 2010; Orosz et al., 2006, 2009; Schneider, 2000). 
Analysis of the locations of the altered residues within the crystal structure of human TPI only reveals a tentative link with severity

The crystal structure of human TPI (PDB: 4POC) (Roland et al., 2015) was visualised and the disease associated variants were located (Figure 1). The positions of these residues within secondary structure elements ( $a$-helix or $\beta$-sheet) along with their relationships to points of interest, primarily the substrate-binding site and dimer interface, were recorded (Figure 1, Table 1, Supplementary Table S1). This revealed that, as noted in previous publications (Li et al., 2013; Rodriguez-Almazan et al., 2008), the Glu104Asp (pathological - severe) variation is very closely related to the dimer interface suggesting a link between severity and the impaired ability of the mutant protein to form a dimer. This residue is also closely related to residue 95 , which plays a key role in the formation of the substratebinding site of the enzyme. The residue of the variant lle170Val (pathological - less severe) is located on the flexible interconnecting loop which forms the lid of the TIM barrel of the substrate binding site, explaining the very low TPI activity reported in this patient (6\%) but is not closely related to the dimer interface potentially explaining why this patient was neurologically intact (Arya et al., 1997; Roland et al., 2015). 
Comparison of the average scores from servers predicting $\Delta \Delta G$ values show some relationship between the severity of the effects of the variation and protein stability

Although there is not a perfect correlation between disease severity and protein stability, the results from the six different servers (I-Mutant 3.0 (Structure and Sequence), mCSM, SDM, CUPSAT and BeAtMuSiC) all show that the average $\Delta \Delta G$ values reported for the pathological (less severe) variants are significantly lower than the corresponding values reported for the pathological (severe) variants (Table 1; Figure 2a). The average of five of these servers (BeAtMuSiC was not included as it reports values differently) revealed that the pathological (less severe) variants had an average $\Delta \Delta G$ value of $0.512 \mathrm{kcal} / \mathrm{mol}$ and the pathological (severe) variants had an average $\Delta \Delta \mathrm{G}$ value of $-2.435 \mathrm{kcal} / \mathrm{mol}$ (Table 1).

Certain servers predicted much more dramatic stability changes than others - for example Phe240Ser had a reported $\Delta \Delta \mathrm{G}$ value of $-1.67 \mathrm{kcal} / \mathrm{mol}$ in I-mutant 3.0 structure compared to $-6.12 \mathrm{kcal} / \mathrm{mol}$ in CUPSAT. In order to rectify this, and to allow for greater ease of comparison between servers, the results of the servers were normalised. This was achieved by dividing each value by the highest value reported in each server for a disease associated variant. It is important to note that in order to use this approach, it must be assumed that each server is equally reliable/accurate. Analysis of the normalised results from those servers which report $\Delta \Delta G$ values shows that, on average, the pathological (severe) mutations have a more dramatic effect on protein stability than the pathological (less severe) mutations -0.202 for the mild mutations compared to 0.631 for the severe mutations.

This contrast can be largely attributed to the much more significant contribution of Phe240Ser than the other pathological (severe) variant, Glu104Asp. The Phe240Ser variant, in the vast majority of cases, is predicted to have the most significant effect on protein stability and/or is reported as being disease-associated with the highest confidence score/reliability index/expected accuracy (Table 1). In those few instances where this is not the case, the respective values are still very high. In contrast to this, the results for Glu104Asp are rather surprising. Although it is, phenotypically, the most severe so far reported, the protein stability results place it in the moderate group. Indeed, a number of servers reported that this variation had among the smallest predicted effect on protein stability.

There was a statistically significant (two way ANOVA with Tukey's correction for multiple comparisons, $p<0.05$ ) difference between the normalised $\Delta \Delta G$ values for the pathological (less severe) and pathological (severe) groups (Figure 2a). However, there was not a significant difference between the pathological (intermediate) group and either of the other two other pathological groups. Therefore, the pathological (intermediate) and pathological (severe) groups were considered together for the analyses of uncharacterised variants. 
The amalgamation of these two groups allowed us to set parameters by which an initial prediction of the likely effect of uncharacterised variants could be made. To do this, it was necessary to define boundaries between three groups of variants: non-pathological, "pathological (less severe)" and pathological (intermediate/severe). To do this, we focussed on the range of $\Delta \Delta G$ values associated with the middle group, pathological (less severe). The upper and lower $95 \%$ confidence interval values of the average $\Delta \Delta G$ values for this group -0.13 and $-0.90 \mathrm{kcal} / \mathrm{mol}$ respectively and these were set as the boundaries. Thus, if the average $\Delta \Delta G$ value of an uncharacterised variant was greater than -0.13 $\mathrm{kcal} / \mathrm{mol}$ it was predicted to be non-pathological. For a prediction of pathological (less severe) the average $\Delta \Delta \mathrm{G}$ value was less than or equal to $-0.13 \mathrm{kcal} / \mathrm{mol}$ but greater than or equal to $-0.90 \mathrm{kcal} / \mathrm{mol}$. If the average $\Delta \Delta G$ value was less than $-0.90 \mathrm{kcal} / \mathrm{mol}$ a prediction of "pathological intermediate/severe" was made.

Application of these parameters to the 79 uncharacterised variants, resulted in a prediction that eight are non-pathological, 34 are pathological (less severe) and 37 are pathological (intermediate/severe) (Table 2; Figure $2 \mathrm{~b}$ ). These assignments are based on data from a relatively small number of clinically and biochemically characterised variants. Therefore, it is possible that they may change as novel variants are characterised and/or the quality of stability prediction improves. Nevertheless these boundaries serve as an important first step towards the development of a predictive framework for TPI deficiency. Furthermore, the good statistical discrimination between the three categories considered (Figure $2 \mathrm{~b}$ ) suggests that the boundaries are robust.

Interestingly, the application of these parameters to the $\Delta \Delta G$ scores of those variants found in healthy heterozygotes also predicted that all four were pathological. It is likely that these variants would result in very low or zero TPI activity if they were to be present in a homozygote or compound heterozygote, as they were associated with a 50\% reduction in TPI activity in the heterozygote carrier (similar to the parents of TPI deficiency cases) (Watanabe et al., 1996). The positions of the corresponding residues of the 79 uncharacterised mutations, within the crystal structure of TPI, were then compared against their predicted disease severity (data not shown). Although this did not reveal any obvious correlation between these two variables, one interesting point to note is that six of the seven residues associated with variation which are predicted to be non-pathological (Ser3, Thr27, Thr89, Gln179, Ser194, Val196) are situated peripherally on the protein and are not part of the substrate binding site or the dimer interface. However a seventh residue (which is associated with two uncharacterised mutations that are predicted to be non-pathological), Asn 71, does form part of the dimer interface.

Aggregation and amyloid formation is not predicted to increase in the disease-associated variants 


\section{Discussion}

Protein stability is an important factor in predicting disease-association and severity of a given mutation but is not the sole factor

In this study, it has been clearly shown that disease-associated variant proteins associated with severe clinical patterns of TPI deficiency are predicted to be significantly more unstable than those associated with comparatively milder progressions. It can, therefore, be said that decreased protein stability is predicted to be associated with increased severity in TPI deficiency. The results from the variants associated with milder forms of the disease, and for lle170Val in particular, also seem to support the conformational disease hypothesis of TPI deficiency (Orosz et al., 2006), due to the observed link between the absence of neurological disease and the presence of a comparatively stable protein. 
However, the imperfect correlation of stability and severity at higher levels, particularly between moderate and severe mutants, the surprisingly low predicted effect of the Glu104Asp variation on protein stability and the apparent lack of a correlation between residue conservation and disease severity all suggest that other factors (e.g. diet, environment, quality of medical care), play a role in the development of this enigmatic disease. Indeed data from a Drosophila study has indicated the existence of an isomerase-independent function of TPI which opens up new avenues of investigation that may prove crucial in developing our understanding of this enzyme in the conservation of normal neuronal function and, therefore, in TPI deficiency pathogenesis (Roland et al., 2015; Roland et al., 2013). Other non-metabolic functions of TPI have also been reported in a number of organisms, mostly pathogens. For instance, the potential role of TPI in adhesin function in the fungal pathogen Paracoccidioides brasiliensis, has been suggested (Pereira et al., 2007). Such interactions are likely to involve the surface of the protein and, therefore, a significant perturbation of its structure would be potentially affect these processes more than catalysis. Thus, the "moonlighting" roles of TPI may also have a role in disease since they are also likely to affected by altered protein stability and folding. Currently, the molecular-level details of these processes have not been explored in detail. It is, therefore, difficult to incorporate them into the predictive model at present.

Towards a predictive framework - key postulates:

Based on the conservation analysis, aggregation predictions and analysis of the stability predictions, four key postulates were made:

1. Variant proteins associated with pathological (intermediate/severe) phenotypes are significantly more unstable than those associated with a pathological (less severe) phenotype.

2. Although the wild-type protein has been shown to form amyloid, the likelihood of aggregation or amyloid formation is not increased in any of the variants. Therefore, these factors do not predict disease-association.

3. Disease-associated variants tend to occur in highly conserved residues. However their severity does not correlate with the degree of conservation.

4. Pathological (intermediate) mutations should be combined with the pathological (severe) group due to the similarities seen in these two groups. 
Conclusions

Overall, our work supports the prevailing view that the pathology of TPI deficiency results largely from alterations to the protein's sequence which alter that stability of the protein with consequent effects of dimerisation and catalysis. From these results we were able to identify a number of variants which are present in the human population which are likely to be associated with pathology. That these variants have not yet been identified as such in patients suggests that these mutations are largely recessive in nature and that disease would only occur in individuals homozygous for these mutations or individuals who are compound heterozygotes for two of these mutations. While our work will not replace the need for laboratory testing in cases of suspected TPI deficiency the approach of predicting protein stability may be useful should new disease-associated variants be discovered. Finally, by reinforcing the concept that protein misfolding lies at the core of this disease we suggest that it may be possible to treat TPI deficiency through the use of small molecules which selectively stabilise TPI ("pharmacological chaperones").

\section{Acknowledgements}

This work received no financial support. CO conducted the stability and sequence conservation analyses. DJT conceived the study, conducted the aggregation predictions and supervised $\mathrm{CO}$. $\mathrm{CO}$ and DJT co-wrote the paper. 
Adzhubei, I.A., Schmidt, S., Peshkin, L., Ramensky, V.E., Gerasimova, A., Bork, P., Kondrashov, A.S., Sunyaev, S.R., 2010. A method and server for predicting damaging missense mutations. Nature methods 7(4), 248-249.

Ahmed, N., Battah, S., Karachalias, N., Babaei-Jadidi, R., Horanyi, M., Baroti, K., Hollan, S., Thornalley, P.J., 2003. Increased formation of methylglyoxal and protein glycation, oxidation and nitrosation in triosephosphate isomerase deficiency. Biochim Biophys Acta 1639(2), 121-132.

Arya, R., Lalloz, M.R., Bellingham, A.J., Layton, D.M., 1997. Evidence for founder effect of the Glu104Asp substitution and identification of new mutations in triosephosphate isomerase deficiency. Hum Mutat 10(4), 290-294.

Ationu, A., Humphries, A., 1998. The feasibility of replacement therapy for inherited disorder of glycolysis: triosephosphate isomerase deficiency (review). International journal of molecular medicine 2(6), 701-704.

Ationu, A., Humphries, A., Bellingham, A., Layton, M., 1997. Metabolic correction of triose phosphate isomerase deficiency in vitro by complementation. Biochem Biophys Res Commun 232(2), 528-531.

Ationu, A., Humphries, A., Lalloz, M.R., Arya, R., Wild, B., Warrilow, J., Morgan, J., Bellingham, A.J., Layton, D.M., 1999a. Reversal of metabolic block in glycolysis by enzyme replacement in triosephosphate isomerase-deficient cells. Blood 94(9), 3193-3198.

Ationu, A., Humphries, A., Wild, B., Carr, T., Will, A., Arya, R., Layton, D.M., 1999b. Towards enzymereplacement treatment in triosephosphate isomerase deficiency. Lancet 353(9159), 1155-1156.

Auer, J., Camoin, L., Courtot, A.M., Hotellier, F., De Almeida, M., 2004. Evidence that P36, a human sperm acrosomal antigen involved in the fertilization process is triosephosphate isomerase. Mol Reprod Dev 68(4), 515-523.

Bang, Y.L., Nguyen, T.T., Trinh, T.T., Kim, Y.J., Song, J., Song, Y.H., 2009. Functional analysis of mutations in UDP-galactose-4-epimerase (GALE) associated with galactosemia in Korean patients using mammalian GALE-null cells. The FEBS journal 276(7), 1952-1961.

Bao, L., Zhou, M., Cui, Y., 2005. nsSNPAnalyzer: identifying disease-associated nonsynonymous single nucleotide polymorphisms. Nucleic acids research 33(Web Server issue), W480-482.

Bardosi, A., Eber, S.W., Hendrys, M., Pekrun, A., 1990. Myopathy with altered mitochondria due to a triosephosphate isomerase (TPI) deficiency. Acta neuropathologica 79(4), 387-394.

Bendl, J., Stourac, J., Salanda, O., Pavelka, A., Wieben, E.D., Zendulka, J., Brezovsky, J., Damborsky, J., 2014. PredictSNP: robust and accurate consensus classifier for prediction of disease-related mutations. PLoS computational biology 10(1), e1003440.

Berman, H.M., Battistuz, T., Bhat, T.N., Bluhm, W.F., Bourne, P.E., Burkhardt, K., Feng, Z., Gilliland, G.L., Iype, L., Jain, S., Fagan, P., Marvin, J., Padilla, D., Ravichandran, V., Schneider, B., Thanki, N., Weissig, H., Westbrook, J.D., Zardecki, C., 2002. The Protein Data Bank. Acta Crystallogr D Biol Crystallogr 58(Pt 6 No 1), 899-907.

Berman, H.M., Westbrook, J., Feng, Z., Gilliland, G., Bhat, T.N., Weissig, H., Shindyalov, I.N., Bourne, P.E., 2000. The Protein Data Bank. Nucleic Acids Res 28(1), 235-242.

Bromberg, Y., Rost, B., 2007. SNAP: predict effect of non-synonymous polymorphisms on function. Nucleic acids research 35(11), 3823-3835.

Browne, C., Timson, D.J., 2015. In Silico Prediction of the Effects of Mutations in the Human Mevalonate Kinase Gene: Towards a Predictive Framework for Mevalonate Kinase Deficiency. Ann Hum Genet 79(6), 451-459.

Capriotti, E., Altman, R.B., Bromberg, Y., 2013. Collective judgment predicts disease-associated single nucleotide variants. BMC genomics 14 Suppl 3, S2-2164-2114-S2163-S2162. Epub 2013 May 2128.

Capriotti, E., Calabrese, R., Casadio, R., 2006. Predicting the insurgence of human genetic diseases associated to single point protein mutations with support vector machines and evolutionary information. Bioinformatics (Oxford, England) 22(22), 2729-2734. 
Capriotti, E., Fariselli, P., Casadio, R., 2005. I-Mutant2.0: predicting stability changes upon mutation from the protein sequence or structure. Nucleic acids research 33(Web Server issue), W306-310.

Capriotti, E., Fariselli, P., Rossi, I., Casadio, R., 2008. A three-state prediction of single point mutations on protein stability changes. BMC bioinformatics 9 Suppl 2, S6-2105-2109-S2102-S2106.

Carcamo-Noriega, E.N., Saab-Rincon, G., 2016. Identification of fibrillogenic regions in human triosephosphate isomerase. PeerJ 4, e1676.

Carvalho, D.R., Brand, G.D., Brum, J.M., Takata, R.I., Speck-Martins, C.E., Pratesi, R., 2012. Analysis of novel ARG1 mutations causing hyperargininemia and correlation with arginase 1 activity in erythrocytes. Gene 509(1), 124-130.

Chang, M.L., Artymiuk, P.J., Wu, X., Hollan, S., Lammi, A., Maquat, L.E., 1993. Human triosephosphate isomerase deficiency resulting from mutation of Phe-240. Am J Hum Genet 52(6), 1260-1269.

Cheng, J., Randall, A., Baldi, P., 2006. Prediction of protein stability changes for single-site mutations using support vector machines. Proteins 62(4), 1125-1132.

Conchillo-Sole, O., de Groot, N.S., Aviles, F.X., Vendrell, J., Daura, X., Ventura, S., 2007. AGGRESCAN: a server for the prediction and evaluation of "hot spots" of aggregation in polypeptides. BMC Bioinformatics 8, 65 .

de Arriba, S.G., Krugel, U., Regenthal, R., Vissiennon, Z., Verdaguer, E., Lewerenz, A., Garcia-Jorda, E., Pallas, M., Camins, A., Munch, G., Nieber, K., Allgaier, C., 2006. Carbonyl stress and NMDA receptor activation contribute to methylglyoxal neurotoxicity. Free Radic Biol Med 40(5), 779-790.

de Arriba, S.G., Stuchbury, G., Yarin, J., Burnell, J., Loske, C., Munch, G., 2007. Methylglyoxal impairs glucose metabolism and leads to energy depletion in neuronal cells - protection by carbonyl scavengers. Neurobiol Aging 28(7), 1044-1050.

De La Mora-De La Mora, I., Torres-Larios, A., Mendoza-Hernandez, G., Enriquez-Flores, S., CastilloVillanueva, A., Mendez, S.T., Garcia-Torres, I., Torres-Arroyo, A., Gomez-Manzo, S., Marcial-Quino, J., Oria-Hernandez, J., Lopez-Velazquez, G., Reyes-Vivas, H., 2013. The E104D mutation increases the susceptibility of human triosephosphate isomerase to proteolysis. Asymmetric cleavage of the two monomers of the homodimeric enzyme. Biochim Biophys Acta 1834(12), 2702-2711.

Dehouck, Y., Kwasigroch, J.M., Rooman, M., Gilis, D., 2013. BeAtMuSiC: Prediction of changes in protein-protein binding affinity on mutations. Nucleic acids research 41(Web Server issue), W333-339. du Plessis, S.S., Agarwal, A., Mohanty, G., van der Linde, M., 2015. Oxidative phosphorylation versus glycolysis: what fuel do spermatozoa use? Asian journal of andrology 17(2), 230-235.

Eber, S.W., Dunnwald, M., Heinemann, G., Hofstatter, T., Weinmann, H.M., Belohradsky, B.H., 1984. Prevalence of partial deficiency of red cell triosephosphate isomerase in Germany--a study of 3000 people. Hum Genet 67(3), 336-339.

Facchiano, A., Marabotti, A., 2010. Analysis of galactosemia-linked mutations of GALT enzyme using a computational biology approach. Protein engineering, design \& selection : PEDS 23(2), 103-113.

Fermo, E., Bianchi, P., Vercellati, C., Rees, D.C., Marcello, A.P., Barcellini, W., Zanella, A., 2010. Triose phosphate isomerase deficiency associated with two novel mutations in TPI gene. European journal of haematology 85(2), 170-173.

Fernandez-Escamilla, A.M., Rousseau, F., Schymkowitz, J., Serrano, L., 2004a. Prediction of sequencedependent and mutational effects on the aggregation of peptides and proteins. Nat Biotechnol 22(10), 1302-1306.

Fernandez-Escamilla, A.M., Rousseau, F., Schymkowitz, J., Serrano, L., 2004b. Prediction of sequencedependent and mutational effects on the aggregation of peptides and proteins. Nature biotechnology 22(10), 1302-1306.

Garbuzynskiy, S.O., Lobanov, M.Y., Galzitskaya, O.V., 2010. FoldAmyloid: a method of prediction of amyloidogenic regions from protein sequence. Bioinformatics 26(3), 326-332.

Hollan, S., Fujii, H., Hirono, A., Hirono, K., Karro, H., Miwa, S., Harsanyi, V., Gyodi, E., Inselt-Kovacs, M., 1993. Hereditary triosephosphate isomerase (TPI) deficiency: two severely affected brothers one with and one without neurological symptoms. Hum Genet 92(5), 486-490. 
Krieger, E., Joo, K., Lee, J., Lee, J., Raman, S., Thompson, J., Tyka, M., Baker, D., Karplus, K., 2009. Improving physical realism, stereochemistry, and side-chain accuracy in homology modeling: Four approaches that performed well in CASP8. Proteins 77 Suppl 9, 114-122.

Kumar, P., Henikoff, S., Ng, P.C., 2009. Predicting the effects of coding non-synonymous variants on protein function using the SIFT algorithm. Nature protocols 4(7), 1073-1081.

Li, Y., Cohenford, M.A., Dutta, U., Dain, J.A., 2008. In vitro nonenzymatic glycation of guanosine 5'triphosphate by dihydroxyacetone phosphate. Analytical and bioanalytical chemistry 392(6), 11891196.

Li, Z., He, Y., Liu, Q., Zhao, L., Wong, L., Kwoh, C.K., Nguyen, H., Li, J., 2013. Structural analysis on mutation residues and interfacial water molecules for human TIM disease understanding. BMC Bioinformatics 14 Suppl 16, S11.

Linding, R., Schymkowitz, J., Rousseau, F., Diella, F., Serrano, L., 2004. A comparative study of the relationship between protein structure and beta-aggregation in globular and intrinsically disordered proteins. J Mol Biol 342(1), 345-353.

Mainfroid, V., Terpstra, P., Beauregard, M., Frere, J.M., Mande, S.C., Hol, W.G., Martial, J.A., Goraj, K., 1996. Three hTIM mutants that provide new insights on why TIM is a dimer. J Mol Biol 257(2), 441456.

Manco, L., Ribeiro, M.L., 2007. Novel human pathological mutations. Gene symbol: TPI1. Disease: triosephosphate isomerase deficiency. Hum Genet 121(5), 650.

Manning, J.R., Bailey, M.A., Soares, D.C., Dunbar, D.R., Mullins, J.J., 2010. In silico structure-function analysis of pathological variation in the HSD11B2 gene sequence. Physiological genomics 42(3), 319330.

McCorvie, T.J., Timson, D.J., 2013. In silico prediction of the effects of mutations in the human UDPgalactose 4'-epimerase gene: Towards a predictive framework for type III galactosemia. Gene 524(2), 95-104.

Merkle, S., Pretsch, W., 1989. Characterization of triosephosphate isomerase mutants with reduced enzyme activity in Mus musculus. Genetics 123(4), 837-844.

Miller, M.P., Kumar, S., 2001. Understanding human disease mutations through the use of interspecific genetic variation. Human molecular genetics 10(21), 2319-2328.

Olah, J., Orosz, F., Keseru, G.M., Kovari, Z., Kovacs, J., Hollan, S., Ovadi, J., 2002. Triosephosphate isomerase deficiency: a neurodegenerative misfolding disease. Biochemical Society transactions 30(2), 30-38.

Olah, J., Orosz, F., Puskas, L.G., Hackler, L., Jr., Horanyi, M., Polgar, L., Hollan, S., Ovadi, J., 2005. Triosephosphate isomerase deficiency: consequences of an inherited mutation at mRNA, protein and metabolic levels. The Biochemical journal 392(Pt 3), 675-683.

Orosz, F., Olah, J., Ovadi, J., 2006. Triosephosphate isomerase deficiency: facts and doubts. IUBMB life 58(12), 703-715.

Orosz, F., Olah, J., Ovadi, J., 2009. Triosephosphate isomerase deficiency: new insights into an enigmatic disease. Biochimica et biophysica acta 1792(12), 1168-1174.

Orosz, F., Vertessy, B.G., Hollan, S., Horanyi, M., Ovadi, J., 1996. Triosephosphate isomerase deficiency: predictions and facts. Journal of theoretical biology 182(3), 437-447.

Parthiban, V., Gromiha, M.M., Schomburg, D., 2006. CUPSAT: prediction of protein stability upon point mutations. Nucleic acids research 34(Web Server issue), W239-242.

Pekrun, A., Neubauer, B.A., Eber, S.W., Lakomek, M., Seidel, H., Schroter, W., 1995. Triosephosphate isomerase deficiency: biochemical and molecular genetic analysis for prenatal diagnosis. Clin Genet 47(4), 175-179.

Pereira, L.A., Bao, S.N., Barbosa, M.S., da Silva, J.L., Felipe, M.S., de Santana, J.M., Mendes-Giannini, M.J., de Almeida Soares, C.M., 2007. Analysis of the Paracoccidioides brasiliensis triosephosphate isomerase suggests the potential for adhesin function. FEMS yeast research 7(8), 1381-1388.

Perry, B.A., Mohrenweiser, H.W., 1992. Human triosephosphate isomerase: substitution of Arg for Gly at position 122 in a thermolabile electromorph variant, TPI-Manchester. Hum Genet 88(6), 634-638. 
Petit, F.M., Serres, C., Auer, J., 2014. Moonlighting proteins in sperm-egg interactions. Biochem Soc Trans 42(6), 1740-1743.

Pires, D.E., Ascher, D.B., Blundell, T.L., 2014. mCSM: predicting the effects of mutations in proteins using graph-based signatures. Bioinformatics (Oxford, England) 30(3), 335-342.

Poinsot, J., Parent, P., Alix, D., Toudic, L., Castel, Y., 1986. A case of congenital non-spherocytic hemolytic anemia caused by triose phosphate isomerase deficiency. Prenatal diagnosis. Journal de genetique humaine 34(5), 431-437.

Ralser, M., Heeren, G., Breitenbach, M., Lehrach, H., Krobitsch, S., 2006. Triose phosphate isomerase deficiency is caused by altered dimerization--not catalytic inactivity--of the mutant enzymes. PloS one 1 , e30.

Rodriguez-Almazan, C., Arreola, R., Rodriguez-Larrea, D., Aguirre-Lopez, B., de Gomez-Puyou, M.T., Perez-Montfort, R., Costas, M., Gomez-Puyou, A., Torres-Larios, A., 2008. Structural basis of human triosephosphate isomerase deficiency: mutation E104D is related to alterations of a conserved water network at the dimer interface. The Journal of biological chemistry 283(34), 23254-23263.

Roland, B.P., Amrich, C.G., Kammerer, C.J., Stuchul, K.A., Larsen, S.B., Rode, S., Aslam, A.A., Heroux, A., Wetzel, R., VanDemark, A.P., Palladino, M.J., 2015. Triosephosphate isomerase I170V alters catalytic site, enhances stability and induces pathology in a Drosophila model of TPI deficiency. Biochim Biophys Acta 1852(1), 61-69.

Roland, B.P., Stuchul, K.A., Larsen, S.B., Amrich, C.G., Vandemark, A.P., Celotto, A.M., Palladino, M.J., 2013. Evidence of a triosephosphate isomerase non-catalytic function crucial to behavior and longevity. J Cell Sci 126(Pt 14), 3151-3158.

Roland, B.P., Zeccola, A.M., Larsen, S.B., Amrich, C.G., Talsma, A.D., Stuchul, K.A., Heroux, A., Levitan, E.S., VanDemark, A.P., Palladino, M.J., 2016. Structural and Genetic Studies Demonstrate Neurologic Dysfunction in Triosephosphate Isomerase Deficiency Is Associated with Impaired Synaptic Vesicle Dynamics. PLoS Genet 12(3), e1005941.

Rosa, R., Prehu, M.O., Calvin, M.C., Daffos, F., Forestier, F., 1986. Possibility of prenatal diagnosis of hereditary triose phosphate isomerase deficiency. Prenat Diagn 6(3), 231-234.

Rousseau, F., Schymkowitz, J., Serrano, L., 2006. Protein aggregation and amyloidosis: confusion of the kinds? Curr Opin Struct Biol 16(1), 118-126.

Sarper, N., Zengin, E., Jakobs, C., Salomons, G.S., Wamelink, M.M., Ralser, M., Kurt, K., Kara, B., 2013. Mild hemolytic anemia, progressive neuromotor retardation and fatal outcome: a disorder of glycolysis, triose-phosphate isomerase deficiency. Turkish Journal of Pediatrics 55, 198-202.

Schneider, A., Valentine, W., Hattori, M., Heins, H., 1964. A new erythrocyte enzyme defect with hemolytic anemia-triosephosphate isomerase (TPI) deficiency. Blood 24(6), 855-856.

Schneider, A.S., 2000. Triosephosphate isomerase deficiency: historical perspectives and molecular aspects. Bailliere's best practice \& research. Clinical haematology 13(1), 119-140.

Schneider, A.S., Valentine, W.N., Hattori, M., Heins, H.L., Jr., 1965. Hereditary hemolytic anemia with triosephosphate isomerase deficiency. N Engl J Med 272, 229-235.

Serdaroglu, G., Aydinok, Y., Yilmaz, S., Manco, L., Ozer, E., 2011. Triosephosphate isomerase deficiency: a patient with Val231Met mutation. Pediatr Neurol 44(2), 139-142.

Shi, Y., Vaden, D.L., Ju, S., Ding, D., Geiger, J.H., Greenberg, M.L., 2005. Genetic perturbation of glycolysis results in inhibition of de novo inositol biosynthesis. J Biol Chem 280(51), 41805-41810.

Sievers, F., Wilm, A., Dineen, D., Gibson, T.J., Karplus, K., Li, W., Lopez, R., McWilliam, H., Remmert, M., Soding, J., Thompson, J.D., Higgins, D.G., 2011. Fast, scalable generation of high-quality protein multiple sequence alignments using Clustal Omega. Molecular systems biology 7, 539 .

Sormanni, P., Aprile, F.A., Vendruscolo, M., 2015. The CamSol method of rational design of protein mutants with enhanced solubility. J Mol Biol 427(2), 478-490.

Stone, E.A., Sidow, A., 2005. Physicochemical constraint violation by missense substitutions mediates impairment of protein function and disease severity. Genome Res 15(7), 978-986.

Stroppolo, M.E., Falconi, M., Caccuri, A.M., Desideri, A., 2001. Superefficient enzymes. Cell Mol Life Sci 58(10), 1451-1460. 
Tartaglia, G.G., Pawar, A.P., Campioni, S., Dobson, C.M., Chiti, F., Vendruscolo, M., 2008. Prediction of aggregation-prone regions in structured proteins. J Mol Biol 380(2), 425-436.

Thomas, P.D., Kejariwal, A., Campbell, M.J., Mi, H., Diemer, K., Guo, N., Ladunga, I., Ulitsky-Lazareva, B., Muruganujan, A., Rabkin, S., Vandergriff, J.A., Doremieux, O., 2003. PANTHER: a browsable database of gene products organized by biological function, using curated protein family and subfamily classification. Nucleic Acids Res 31(1), 334-341.

Timson, D.J., 2015. Value of predictive bioinformatics in inherited metabolic diseases. World Journal of Medical Genetics 5, 46-51.

Valdar, W.S., 2002. Scoring residue conservation. Proteins 48(2), 227-241.

Valentin, C., Cohen-Solal, M., Maquat, L., Horanyi, M., Inselt-Kovacs, M., Hollan, S., 2000. Identical germ-line mutations in the triosephosphate isomerase alleles of two brothers are associated with distinct clinical phenotypes. C R Acad Sci III 323(3), 245-250.

Watanabe, M., Zingg, B.C., Mohrenweiser, H.W., 1996. Molecular analysis of a series of alleles in humans with reduced activity at the triosephosphate isomerase locus. Am J Hum Genet 58(2), 308316.

Wilmshurst, J.M., Wise, G.A., Pollard, J.D., Ouvrier, R.A., 2004. Chronic axonal neuropathy with triosephosphate isomerase deficiency. Pediatr Neurol 30(2), 146-148.

Worth, C.L., Preissner, R., Blundell, T.L., 2011. SDM - a server for predicting effects of mutations on protein stability and malfunction. Nucleic acids research 39(Web Server issue), W215-222. 


\section{Figure legends}

Figure 1: The three dimensional structure of dimeric human wild-type TPI (PDB: 4POC) (Roland et al., 2015), visualised using PyMol, with residues associated with known, disease-associated variants highlighted in blue and shown in stick format overlaid with space-filling spheres. The protein consists of two identical monomers, shown in light purple and cyan. Disease-associated residues are only highlighted on the left hand subunit. Note that Val-231 and Phe-240 are in contact with each other.

Figure 2: Summary of stability predictions by group. (a) The well-characterised, disease-associated variants were grouped by clinical features. The lack of significant difference between the pathological (intermediate) and pathological (severe) group resulted in the combination of these two groups it subsequent analyses. (b) The uncharacterised variants were grouped by their predicted severity. ns, not significant; ${ }^{* *} \mathrm{p}<0.01{ }^{* * * *} \mathrm{p}<0.0001$ (two way ANOVA with Tukey's correction for multiple comparisons). Each point represents a normalised mean value (derived from six different prediction methods) for a single variant. The wide bar represents the mean of all values in the group and the narrower bars one standard deviation of this mean. 


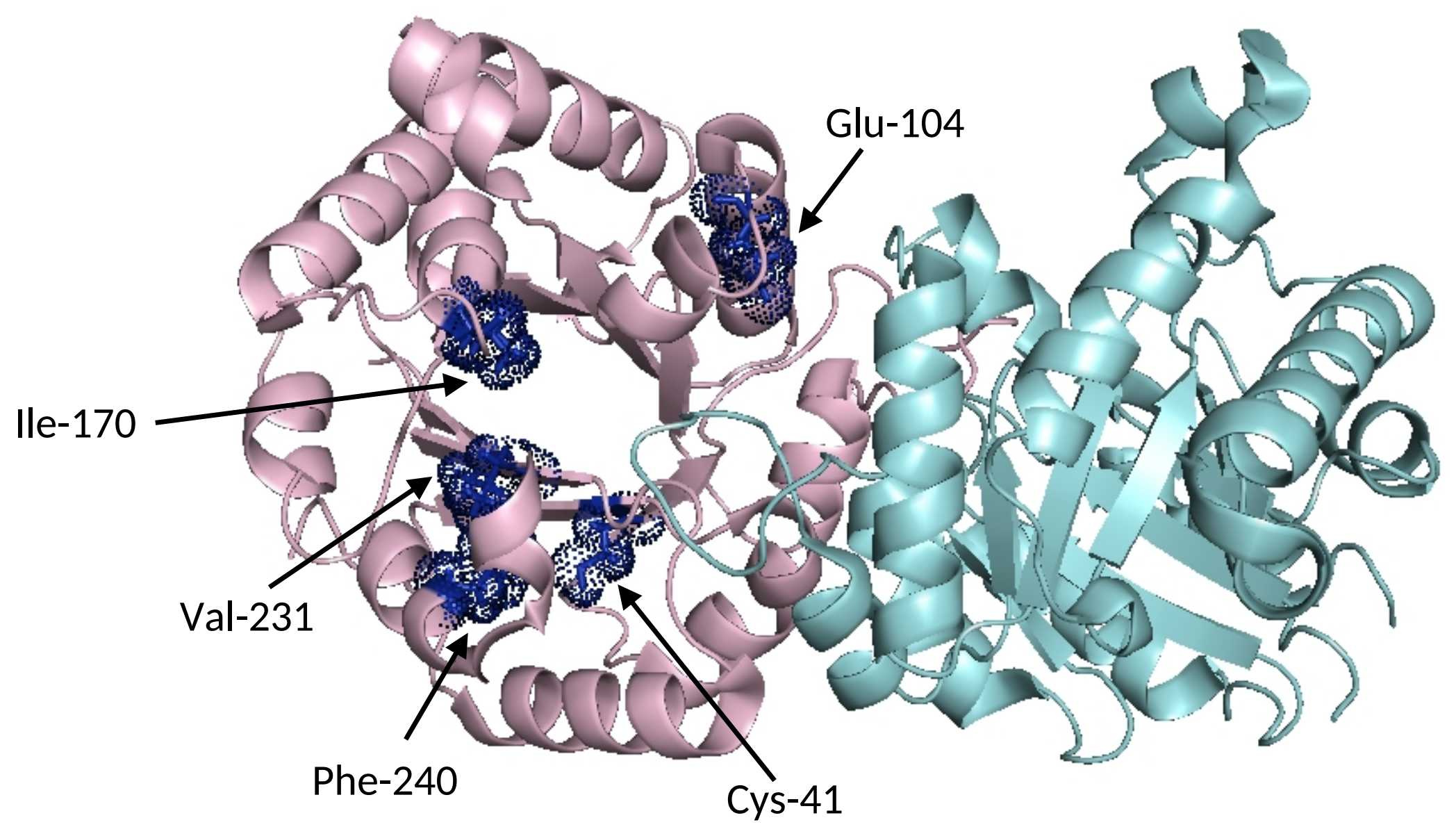


(a)

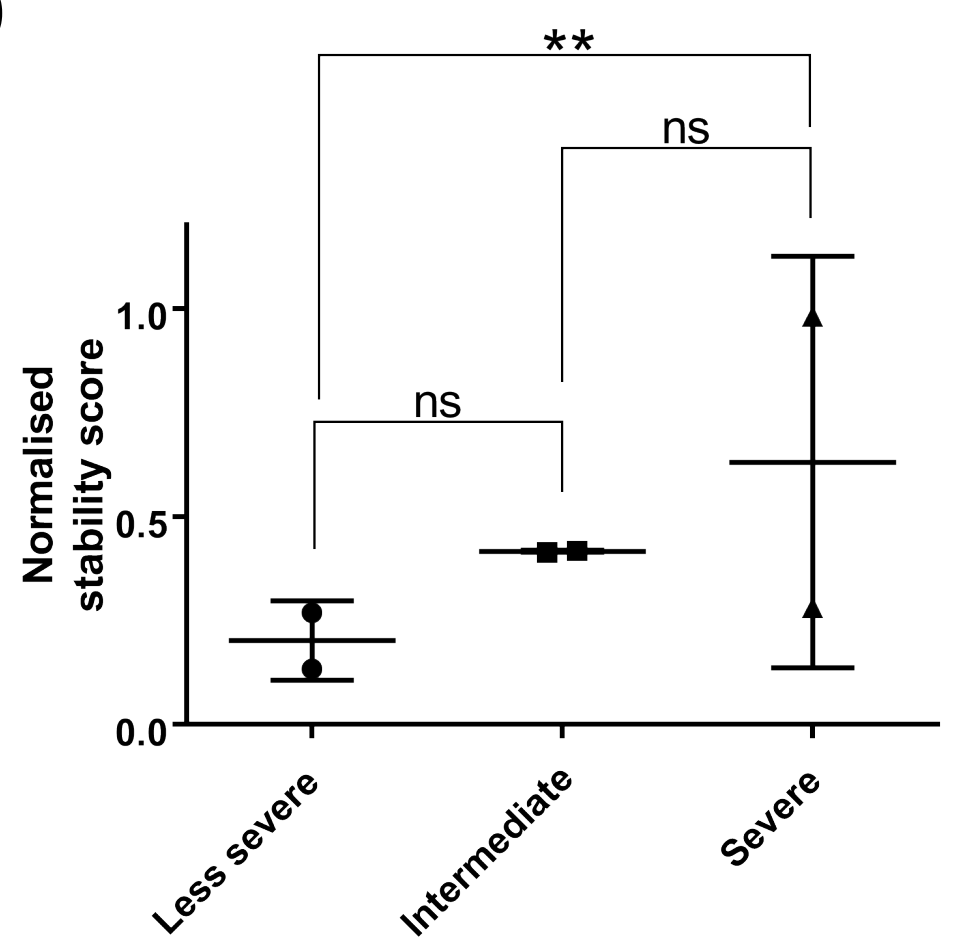

(b)

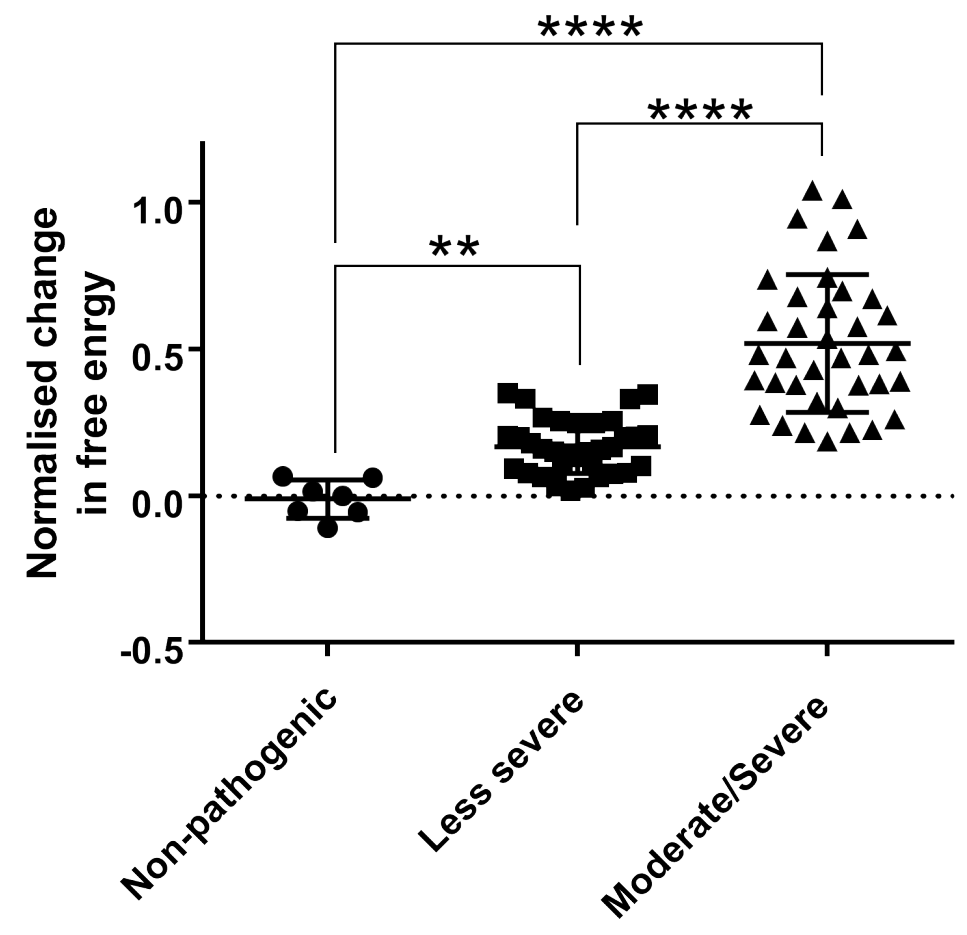


Tables

Table 1: Results of conservation analysis, structural analysis, and the average of those results from $\Delta \Delta G$ prediction servers for characterised variants and those variants reported in healthy heterozygotes.

\begin{tabular}{|c|c|c|c|c|}
\hline Variant & $\begin{array}{c}\text { Average } \\
\Delta \Delta \mathrm{G} \text { Value } \\
\left(\mathrm{kcal} \mathrm{mol}^{-1}\right)\end{array}$ & $\begin{array}{c}\text { Degree of } \\
\text { Conservation }\end{array}$ & Position of the altered residue & $\begin{array}{l}\text { Associated/predicted } \\
\text { severity }\end{array}$ \\
\hline Cys41Tyr & -2.60 & $43.8 \%$ & $\begin{array}{l}\text { Towards C-terminal end of } 2 \text { nd } \beta \text { - } \\
\text { sheet }\end{array}$ & $\begin{array}{c}\text { Pathological } \\
\text { (moderate/severe) }\end{array}$ \\
\hline Ala62Asp & -2.08 & $56.4 \%$ & Middle of 3rd $\beta$-sheet & $\begin{array}{c}\text { PREDICTED: } \\
\text { Pathological } \\
\text { (moderate/severe) }\end{array}$ \\
\hline Gly72Ala & -0.38 & $83.4 \%$ & $\begin{array}{l}\text { Middle of interconnecting loop } \\
\text { between } 3 r d \beta \text {-sheet and 3rd } \alpha \text {-helix }\end{array}$ & $\begin{array}{l}\text { PREDICTED: } \\
\text { Pathological (less } \\
\text { severe) }\end{array}$ \\
\hline Glu104Asp & -1.41 & $100 \%$ & $\begin{array}{l}\text { Middle of interconnecting loop } \\
\text { between 4th and 5th a-helix }\end{array}$ & $\begin{array}{c}\text { Pathological } \\
\text { (moderate/severe) }\end{array}$ \\
\hline Gly122Arg & -0.13 & $50.1 \%$ & $\mathrm{~N}$-terminal end of 5 th $\beta$-sheet & $\begin{array}{l}\text { PREDICTED: } \\
\text { Pathological (less } \\
\text { severe) }\end{array}$ \\
\hline Val154Met & -1.31 & $70.1 \%$ & $\begin{array}{l}\mathrm{N} \text {-terminal end of interconnecting } \\
\text { loop between } 7 \text { th } \alpha \text {-helix and } 6 \text { th } \beta \text { - } \\
\text { sheet }\end{array}$ & $\begin{array}{c}\text { PREDICTED: } \\
\text { Pathological } \\
\text { (moderate/severe) }\end{array}$ \\
\hline Ile170Val & -0.43 & $100 \%$ & $\begin{array}{l}\text { Middle of interconnecting loop } \\
\text { between } 6 \text { th } \beta \text {-sheet and 8th } \alpha \text {-helix }\end{array}$ & $\begin{array}{c}\text { Pathological (less } \\
\text { severe) }\end{array}$ \\
\hline Val231Met & -1.95 & $92.5 \%$ & $\begin{array}{l}\text { C- terminal end of } 8 \text { th } \beta \text {-sheet. Part of } \\
\text { substrate binding site }\end{array}$ & $\begin{array}{c}\text { Pathological } \\
\text { (moderate/severe) }\end{array}$ \\
\hline Phe240Leu & -0.59 & $93.9 \%$ & $\begin{array}{l}\text { Towards N-terminal end of } 12 \text { th } a- \\
\text { helix }\end{array}$ & $\begin{array}{c}\text { Pathological (less } \\
\text { severe) }\end{array}$ \\
\hline Phe240Ser & -3.46 & $93.9 \%$ & $\begin{array}{l}\text { Towards N-terminal end of } 12 \text { th a- } \\
\text { helix }\end{array}$ & $\begin{array}{c}\text { Pathological } \\
\text { (moderate/severe) }\end{array}$ \\
\hline
\end{tabular}


Table 2: Results of conservation analysis, structural analysis, and the average of those results from $\Delta \Delta G$ prediction servers for each of the 79 "uncharacterised" variants from the dbSNP database, along with their predicted severity.

\begin{tabular}{|c|c|c|c|c|}
\hline Variant & $\begin{array}{l}\text { Average } \Delta \Delta G \\
\text { Value (kcal } \\
\left.\text { mol }^{-1}\right)\end{array}$ & $\begin{array}{c}\text { Degree of } \\
\text { Conservation }\end{array}$ & Position of the altered residue & $\begin{array}{l}\text { Prediction of } \\
\text { severity }\end{array}$ \\
\hline Ser3Ala & 0.18 & $34.0 \%$ & $\begin{array}{l}\text { N-terminal of first loop before 1st } \beta \text { - } \\
\text { sheet }\end{array}$ & Non-Pathological \\
\hline Arg4Gly & -1.93 & $64.9 \%$ & $\begin{array}{l}\text { Middle of initial loop before 1st } \beta \text { - } \\
\text { sheet }\end{array}$ & $\begin{array}{c}\text { Pathological } \\
\text { (moderate/severe) }\end{array}$ \\
\hline Phe6lle & -0.93 & $51.6 \%$ & $\mathrm{~N}$-terminal end of 1 st $\beta$-sheet & $\begin{array}{c}\text { Pathological } \\
\text { (moderate/severe) }\end{array}$ \\
\hline Phe6Leu & -1.05 & $51.6 \%$ & $\mathrm{~N}$-terminal end of 1 st $\beta$-sheet & $\begin{array}{c}\text { Pathological } \\
\text { (moderate/severe) }\end{array}$ \\
\hline Val8Ala & -2.04 & $71.2 \%$ & $\begin{array}{l}\text { Middle of } 1 \text { st } \beta \text {-sheet. Near to } \\
\text { substrate binding site }\end{array}$ & $\begin{array}{c}\text { Pathological } \\
\text { (moderate/severe) }\end{array}$ \\
\hline Asn11Asp & -0.15 & $77.8 \%$ & $\begin{array}{l}\text { C-terminal end of } 1 \text { st } \beta \text {-sheet. Key } \\
\text { residues of the substrate binding site. }\end{array}$ & $\begin{array}{l}\text { Pathological (less } \\
\text { severe) }\end{array}$ \\
\hline Asn11Lys & -0.43 & $77.8 \%$ & $\begin{array}{l}C \text {-terminal end of } 1 \text { st } \beta \text {-sheet. Key } \\
\text { residue of substrate binding site. }\end{array}$ & $\begin{array}{l}\text { Pathological (less } \\
\text { severe) }\end{array}$ \\
\hline Trp12Gly & -1.60 & $63.1 \%$ & $\begin{array}{l}\mathrm{N} \text { - terminal end of interconnecting } \\
\text { loop between } 1 \text { st } \beta \text {-sheet and } 1 \text { st } \alpha \text { - } \\
\text { helix. Near substrate binding site }\end{array}$ & $\begin{array}{c}\text { Pathological } \\
\text { (moderate/severe) }\end{array}$ \\
\hline Met14lle & -0.92 & $53.9 \%$ & $\begin{array}{l}\text { Middle of interconnecting loop } \\
\text { between } 1 \text { st } \beta \text {-sheet and 1st } \alpha \text {-helix. } \\
\text { Near substrate binding site and part of } \\
\text { dimer interface }\end{array}$ & $\begin{array}{c}\text { Pathological } \\
\text { (moderate/severe) }\end{array}$ \\
\hline Gly16Val & -0.31 & $62.5 \%$ & $\begin{array}{l}\text { Towards C-terminal end of } \\
\text { interconnecting loop between 1st } \beta \text { - } \\
\text { sheet and 1st } \alpha \text {-helix. Part of dimer } \\
\text { interface }\end{array}$ & $\begin{array}{l}\text { Pathological (less } \\
\text { severe) }\end{array}$ \\
\hline Ser20Asn & -0.20 & $35.5 \%$ & $\begin{array}{l}\text { Towards N-terminal of 1st a-helix. } \\
\text { Near dimer interface }\end{array}$ & $\begin{array}{l}\text { Pathological (less } \\
\text { severe) }\end{array}$ \\
\hline Leu24Val & -1.14 & $52.6 \%$ & Middle of 1st a-helix. & $\begin{array}{c}\text { Pathological } \\
\text { (moderate/severe) }\end{array}$ \\
\hline Thr27lle & 0.88 & $40.5 \%$ & Towards C-terminal end of 1st a-helix & Non-Pathological \\
\hline Val33Leu & -0.92 & $48.9 \%$ & $\begin{array}{l}\text { Middle of interconnecting loop } \\
\text { between 1st } \alpha \text {-helix and } 2 \text { nd } \beta \text {-sheet }\end{array}$ & $\begin{array}{c}\text { Pathological } \\
\text { (moderate/severe) }\end{array}$ \\
\hline Thr37Ala & -0.39 & $47.9 \%$ & $\mathrm{~N}$-terminal end of $2 \mathrm{nd} \beta$-sheet. & $\begin{array}{l}\text { Pathological (less } \\
\text { severe) }\end{array}$ \\
\hline
\end{tabular}




\begin{tabular}{|c|c|c|c|c|}
\hline Glu38Asp & -0.88 & $59.0 \%$ & $\begin{array}{l}\text { Towards N-terminal end of } 2 \mathrm{nd} \beta \text { - } \\
\text { sheet }\end{array}$ & $\begin{array}{l}\text { Pathological (less } \\
\text { severe) }\end{array}$ \\
\hline Glu38Lys & -0.58 & $59.0 \%$ & $\begin{array}{l}\text { Towards } N \text {-terminal end of } 2 \text { nd } \beta \text { - } \\
\text { sheet }\end{array}$ & $\begin{array}{l}\text { Pathological (less } \\
\text { severe) }\end{array}$ \\
\hline Val39Leu & -0.22 & $65.7 \%$ & Middle of 2 nd $\beta$-sheet & $\begin{array}{l}\text { Pathological (less } \\
\text { severe) }\end{array}$ \\
\hline Ala46Val & -0.46 & $42.8 \%$ & $\begin{array}{l}\text { Towards c-terminal end of } \\
\text { interconnecting loop between } 2 \text { nd } \beta \text { - } \\
\text { sheet and } 2 \text { nd } a-- \text {-helix. Near dimer } \\
\text { interface }\end{array}$ & $\begin{array}{l}\text { Pathological (less } \\
\text { severe) }\end{array}$ \\
\hline Ala51Thr & -1.91 & $52.5 \%$ & $\begin{array}{l}\text { Middle of 2nd a-helix. Near dimer } \\
\text { interface }\end{array}$ & $\begin{array}{c}\text { Pathological } \\
\text { (moderate/severe) }\end{array}$ \\
\hline Arg52Gln & -0.51 & $52.8 \%$ & $\begin{array}{l}\text { Middle of 2nd a-helix. Near dimer } \\
\text { interface }\end{array}$ & $\begin{array}{l}\text { Pathological (less } \\
\text { severe) }\end{array}$ \\
\hline Lys58Arg & -0.55 & $41.0 \%$ & $\begin{array}{l}\text { Near C-terminal end of } \\
\text { interconnecting loop between } 2 \text { nd } \alpha \text { - } \\
\text { helix and } 3 \text { rd } \beta \text {-sheet }\end{array}$ & $\begin{array}{l}\text { Pathological (less } \\
\text { severe) }\end{array}$ \\
\hline Ile59Met & -0.68 & $53.5 \%$ & $\begin{array}{l}\text { C-terminal end of interconnecting } \\
\text { loop between } 2 \text { nd } \alpha \text {-helix and } 3 \text { rd } \beta \text { - } \\
\text { sheet }\end{array}$ & $\begin{array}{l}\text { Pathological (less } \\
\text { severe) }\end{array}$ \\
\hline Ala63Ser & -1.60 & $71.6 \%$ & $\begin{array}{l}\text { C-terminal end of } 3 r d \beta \text {-sheet. Near } \\
\text { dimer interface }\end{array}$ & $\begin{array}{c}\text { Pathological } \\
\text { (moderate/severe) }\end{array}$ \\
\hline Val69Met & -0.88 & $37.1 \%$ & $\begin{array}{l}\text { Part of interconnecting loop between } \\
\text { 3rd } \beta \text {-sheet and 3rd } a \text {-helix. Part of } \\
\text { dimer interface }\end{array}$ & $\begin{array}{l}\text { Pathological (less } \\
\text { severe) }\end{array}$ \\
\hline Asn71Thr & 0.17 & $42.0 \%$ & $\begin{array}{l}\text { Part of interconnecting loop between } \\
\text { 3rd } \beta \text {-sheet and 3rd } a \text {-helix. Part of } \\
\text { dimer interface }\end{array}$ & Non-Pathological \\
\hline Asn71Lys & -0.08 & $42.0 \%$ & $\begin{array}{l}\text { Part of interconnecting loop between } \\
\text { 3rd } \beta \text {-sheet and 3rd } a \text {-helix. Part of } \\
\text { dimer interface }\end{array}$ & Non-Pathological \\
\hline Ala88Pro & -0.27 & $57.8 \%$ & $\begin{array}{l}\text { Middle of interconnecting loop } \\
\text { between } 3 r d a \text {-helix and } 4 \text { th } \beta \text {-sheet. } \\
\text { Near dimer interface }\end{array}$ & $\begin{array}{l}\text { Pathological (less } \\
\text { severe) }\end{array}$ \\
\hline Thr89Met & 0.13 & $46.7 \%$ & $\begin{array}{l}\text { C-terminal end of interconnecting } \\
\text { loop between 3rd } \alpha \text {-helix and 4th } \beta \text { - } \\
\text { sheet }\end{array}$ & Non-Pathological \\
\hline Val91Ala & -2.54 & $83.5 \%$ & $\begin{array}{l}\text { Middle of } 4 \text { th } \beta \text {-sheet. Near substrate } \\
\text { binding site }\end{array}$ & $\begin{array}{c}\text { Pathological } \\
\text { (moderate/severe) }\end{array}$ \\
\hline Arg99Ser & -1.71 & $95.4 \%$ & $\begin{array}{l}\text { Middle of } 4 \text { th a-helix. Near substrate } \\
\text { binding site and dimer interface }\end{array}$ & $\begin{array}{c}\text { Pathological } \\
\text { (moderate/severe) }\end{array}$ \\
\hline
\end{tabular}




\begin{tabular}{|c|c|c|c|c|}
\hline Ala118Thr & -0.76 & $49.1 \%$ & C-terminal end of 5th a-helix & $\begin{array}{l}\text { Pathological (less } \\
\text { severe) }\end{array}$ \\
\hline Val123Ala & -2.74 & $78.0 \%$ & $\begin{array}{l}\mathrm{N} \text {-terminal end of } 5 \text { th } \beta \text {-sheet. Near } \\
\text { substrate binding site }\end{array}$ & $\begin{array}{c}\text { Pathological } \\
\text { (moderate/severe) }\end{array}$ \\
\hline Val123Ile & -0.75 & $78.0 \%$ & $\begin{array}{l}\mathrm{N} \text {-terminal end of } 5 \text { th } \beta \text {-sheet. Near } \\
\text { substrate binding site }\end{array}$ & $\begin{array}{l}\text { Pathological (less } \\
\text { severe) }\end{array}$ \\
\hline Ala125Thr & -1.71 & $64.1 \%$ & $\begin{array}{l}\text { Middle of } 5 \text { th } \beta \text {-sheet. Near substrate } \\
\text { binding site }\end{array}$ & $\begin{array}{c}\text { Pathological } \\
\text { (moderate/severe) }\end{array}$ \\
\hline Ile127Asn & -3.30 & $80.1 \%$ & $\begin{array}{l}\text { C-terminal end of } 5 \text { th } \beta \text {-sheet. Near } \\
\text { substrate binding site }\end{array}$ & $\begin{array}{c}\text { Pathological } \\
\text { (moderate/severe) }\end{array}$ \\
\hline Val143Leu & -0.37 & $76.4 \%$ & Part of the 7th a-helix. & $\begin{array}{c}\text { Pathological (less } \\
\text { severe) }\end{array}$ \\
\hline Phe144Ser & -2.38 & $46.1 \%$ & Part of the 7th a-helix. & $\begin{array}{c}\text { Pathological } \\
\text { (moderate/severe) }\end{array}$ \\
\hline Gln146His & -0.41 & $94.9 \%$ & Part of the 7th a-helix. & $\begin{array}{c}\text { Pathological (less } \\
\text { severe) }\end{array}$ \\
\hline Thr147Arg & -1.18 & $61.0 \%$ & Part of the 7th a-helix. & $\begin{array}{c}\text { Pathological } \\
\text { (moderate/severe) }\end{array}$ \\
\hline Val149Phe & -0.66 & $58.8 \%$ & Near c-terminal end of 7 th $a$-helix. & $\begin{array}{c}\text { Pathological (less } \\
\text { severe) }\end{array}$ \\
\hline Ile150Met & -1.45 & $67.0 \%$ & Near c-terminal end of 7 th $a$-helix. & $\begin{array}{c}\text { Pathological } \\
\text { (moderate/severe) }\end{array}$ \\
\hline Asn153Lys & -0.61 & $50.5 \%$ & C-terminal end of 7th a-helix. & $\begin{array}{c}\text { Pathological (less } \\
\text { severe) }\end{array}$ \\
\hline Val154Ala & -2.12 & $70.1 \%$ & $\begin{array}{l}\mathrm{N} \text {-terminal end of interconnecting } \\
\text { loop between the } 7 \text { th } \alpha \text {-helix and the } \\
\text { 6th } \beta \text {-sheet }\end{array}$ & $\begin{array}{c}\text { Pathological } \\
\text { (moderate/severe) }\end{array}$ \\
\hline Trp157Gly & -2.57 & $68.6 \%$ & $\begin{array}{l}\text { Middle of interconnecting loop } \\
\text { between the 7th } \alpha \text {-helix and the 6th } \\
\beta \text {-sheet }\end{array}$ & $\begin{array}{c}\text { Pathological } \\
\text { (moderate/severe) }\end{array}$ \\
\hline Lys159Glu & -0.20 & $61.2 \%$ & $\begin{array}{l}\mathrm{N} \text {-terminal end of interconnecting } \\
\text { loop between the } 7 \text { th } \alpha \text {-helix and the } \\
\text { 6th } \beta \text {-sheet }\end{array}$ & $\begin{array}{l}\text { Pathological (less } \\
\text { severe) }\end{array}$ \\
\hline Val161lle & -0.40 & $91.3 \%$ & $\begin{array}{l}\text { Near } N \text {-terminal end of } 6 \text { th } \beta \text {-sheet. } \\
\text { Near substrate binding site }\end{array}$ & $\begin{array}{l}\text { Pathological (less } \\
\text { severe) }\end{array}$ \\
\hline Ala163Ser & -2.29 & $100.0 \%$ & $\begin{array}{l}\text { Part of } 6 \text { th } \beta \text {-sheet. Near substrate } \\
\text { binding site }\end{array}$ & $\begin{array}{c}\text { Pathological } \\
\text { (moderate/severe) }\end{array}$ \\
\hline Ala176Glu & -0.95 & $98.4 \%$ & $\begin{array}{l}\text { Towards C-terminal end of } \\
\text { interconnecting loop between 6th } \beta \text { - } \\
\text { sheet and 8th a-helix. Near substrate } \\
\text { binding site }\end{array}$ & $\begin{array}{c}\text { Pathological } \\
\text { (moderate/severe) }\end{array}$ \\
\hline
\end{tabular}




\begin{tabular}{|c|c|c|c|c|}
\hline Pro178Thr & -0.26 & $81.6 \%$ & $\mathrm{~N}$-terminal end of 8th $a$-helix & severe) \\
\hline Gln179Lys & 0.10 & $59.1 \%$ & Towards N-terminal end of 8th a-helix & Non-Pathological \\
\hline Ala181Gly & -2.39 & $90.5 \%$ & $\begin{array}{l}\text { Towards N-terminal end of 8th a- } \\
\text { helix. }\end{array}$ & $\begin{array}{c}\text { Pathological } \\
\text { (moderate/severe) }\end{array}$ \\
\hline Gln182Arg & -0.49 & $87.2 \%$ & Part of 8th a-helix. & $\begin{array}{c}\text { Pathological (less } \\
\text { severe) }\end{array}$ \\
\hline His185Gln & -1.09 & $88.1 \%$ & Part of 8th a-helix & $\begin{array}{c}\text { Pathological } \\
\text { (moderate/severe) }\end{array}$ \\
\hline Glu186Lys & -0.53 & $52.7 \%$ & Part of 8th a-helix & $\begin{array}{c}\text { Pathological (less } \\
\text { severe) }\end{array}$ \\
\hline Glu186Gly & -1.43 & $52.7 \%$ & Part of 8th a-helix & $\begin{array}{c}\text { Pathological } \\
\text { (moderate/severe) }\end{array}$ \\
\hline Trp191Cys & -1.29 & $63.2 \%$ & Part of 8th a-helix & $\begin{array}{c}\text { Pathological } \\
\text { (moderate/severe) }\end{array}$ \\
\hline Leu192GIn & -2.92 & $75.3 \%$ & Part of 8th a-helix & $\begin{array}{c}\text { Pathological } \\
\text { (moderate/severe) }\end{array}$ \\
\hline Ser194Phe & -0.06 & $46.3 \%$ & Towards C-terminal end of 8th a-helix & Non-Pathological \\
\hline Val196Ile & -0.10 & $62.8 \%$ & C-terminal end of 8th a-helix & Non-Pathological \\
\hline Ala199Val & -0.60 & $49.5 \%$ & Towards N-terminal end of 9th a-helix & $\begin{array}{c}\text { Pathological (less } \\
\text { severe) }\end{array}$ \\
\hline Val200Gly & -2.65 & $76.2 \%$ & Part of 9th a-helix & $\begin{array}{c}\text { Pathological } \\
\text { (moderate/severe) }\end{array}$ \\
\hline Thr204lle & -0.28 & $60.5 \%$ & $\begin{array}{l}\text { Interconnecting loop between 9th } \alpha \text { - } \\
\text { helix and 7th } \beta \text {-sheet }\end{array}$ & $\begin{array}{c}\text { Pathological (less } \\
\text { severe) }\end{array}$ \\
\hline Thr204Ser & -1.84 & $60.5 \%$ & $\begin{array}{l}\text { Interconnecting loop between 9th a- } \\
\text { helix and 7th } \beta \text {-sheet }\end{array}$ & $\begin{array}{c}\text { Pathological } \\
\text { (moderate/severe) }\end{array}$ \\
\hline Arg205His & -0.64 & $85.9 \%$ & $\begin{array}{l}\text { Interconnecting loop between 9th a- } \\
\text { helix and 7th } \beta \text {-sheet }\end{array}$ & $\begin{array}{c}\text { Pathological (less } \\
\text { severe) }\end{array}$ \\
\hline Arg205Cys & -2.72 & $85.9 \%$ & $\begin{array}{l}\text { Interconnecting loop between 9th a- } \\
\text { helix and 7th } \beta \text {-sheet }\end{array}$ & $\begin{array}{c}\text { Pathological } \\
\text { (moderate/severe) }\end{array}$ \\
\hline Tyr208Cys & -0.31 & $100.0 \%$ & $\begin{array}{l}\text { C-terminal end of } 7 \text { th } \beta \text {-sheet. Near } \\
\text { substrate binding site }\end{array}$ & $\begin{array}{c}\text { Pathological (less } \\
\text { severe) }\end{array}$ \\
\hline Val212Met & -0.95 & $97.1 \%$ & $\begin{array}{l}\text { Middle of interconnecting loop } \\
\text { between } 7 \text { th } \beta \text {-sheet and 10th } \alpha \text {-helix. } \\
\text { Near substrate binding site }\end{array}$ & $\begin{array}{c}\text { Pathological } \\
\text { (moderate/severe) }\end{array}$ \\
\hline Glu219Asp & -0.64 & $77.7 \%$ & Middle of 10 th a-helix. & $\begin{array}{c}\text { Pathological (less } \\
\text { severe) }\end{array}$ \\
\hline Leu220Val & -1.30 & $91.0 \%$ & Middle of 10th a-helix & Pathological \\
\hline
\end{tabular}




\begin{tabular}{|c|c|c|c|c|}
\hline & & & & (moderate/severe) \\
\hline Ser222Gly & -1.00 & $49.5 \%$ & C-terminal end of 10th a-helix & $\begin{array}{c}\text { Pathological } \\
\text { (moderate/severe) }\end{array}$ \\
\hline Asp225Gly & -1.54 & $84.5 \%$ & $\begin{array}{l}\text { Interconnecting loop between 10th a- } \\
\text { helix and 8th } \beta \text {-sheet }\end{array}$ & $\begin{array}{c}\text { Pathological } \\
\text { (moderate/severe) }\end{array}$ \\
\hline Val231Ala & -2.77 & $92.5 \%$ & $\begin{array}{l}\text { C- terminal end of } 8 \text { th } \beta \text {-sheet. Part of } \\
\text { substrate binding site }\end{array}$ & $\begin{array}{c}\text { Pathological } \\
\text { (moderate/severe) }\end{array}$ \\
\hline Lys237Arg & -0.37 & $82.2 \%$ & $\begin{array}{l}\text { Interconnecting loop between 11th } \\
\text { and 12th } a \text { - helices. Near dimer } \\
\text { interface }\end{array}$ & $\begin{array}{l}\text { Pathological (less } \\
\text { severe) }\end{array}$ \\
\hline Pro238Ser & -0.65 & $63.9 \%$ & $\mathrm{~N}$-terminal end of 12 th $\mathrm{a}$-helix & $\begin{array}{l}\text { Pathological (less } \\
\text { severe) }\end{array}$ \\
\hline Glu239Lys & -1.11 & $67.3 \%$ & $\begin{array}{l}\text { Towards N-terminal end of } 12 \text { th a- } \\
\text { helix }\end{array}$ & $\begin{array}{c}\text { Pathological } \\
\text { (moderate/severe) }\end{array}$ \\
\hline Asp242Tyr & -0.16 & $61.7 \%$ & Middle of 12th a-helix & $\begin{array}{l}\text { Pathological (less } \\
\text { severe) }\end{array}$ \\
\hline Ile243Val & -1.11 & $94.1 \%$ & Middle of 12th a-helix. & $\begin{array}{c}\text { Pathological } \\
\text { (moderate/severe) }\end{array}$ \\
\hline Asn245Ser & -0.53 & $68.4 \%$ & C-terminal end of 12th a-helix. & $\begin{array}{c}\text { Pathological (less } \\
\text { severe) }\end{array}$ \\
\hline
\end{tabular}


(a)

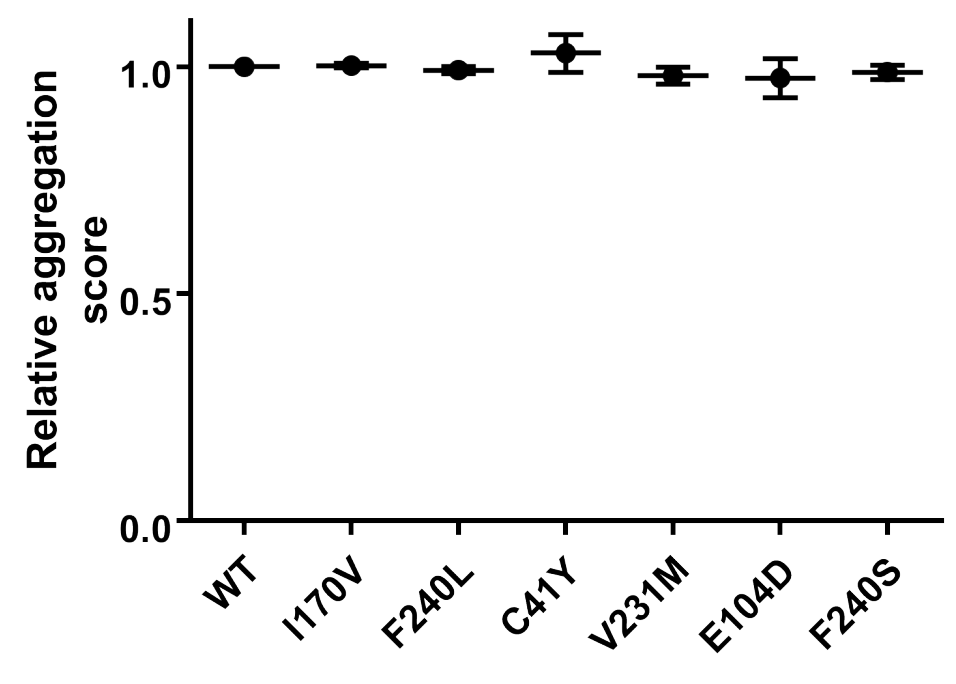

Variant (b)

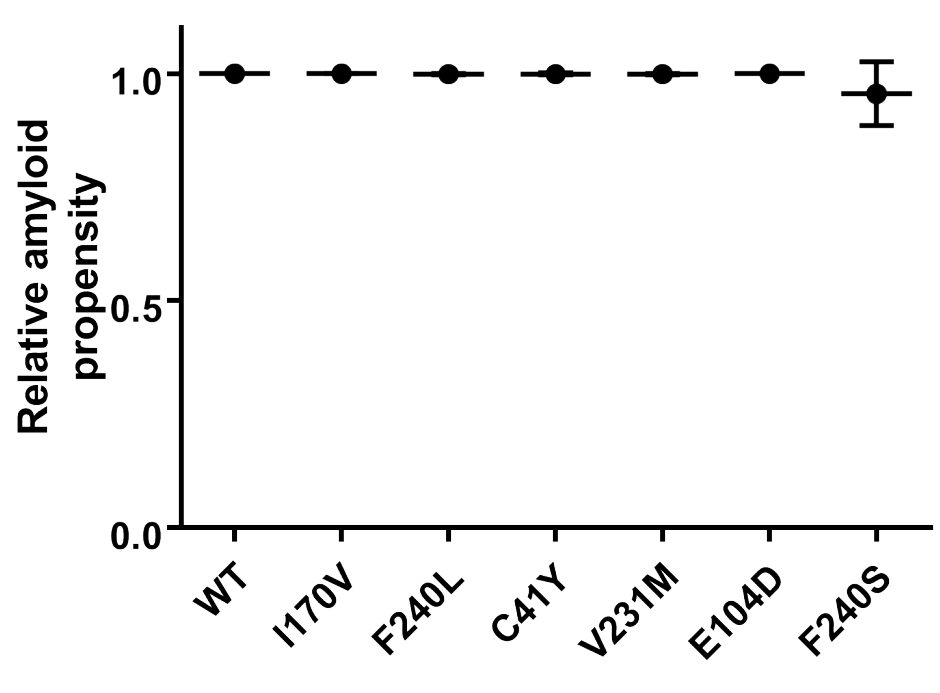

Variant

Supplementary figure S1: Comparison of the normalised aggregation scores (a) and amyloid propensity scores (b) for wild-type human triose phosphate isomerase and six disease-associated variants. No statistically significant difference was detected between the score for the wild-type and any of the variants (one way ANOVA comparing each variant with the wild-type). Each point and long bar represents the mean score (normalised against the score for WT) from the prediction servers. The shorter bars represent one standard deviation of these means. 
(a)

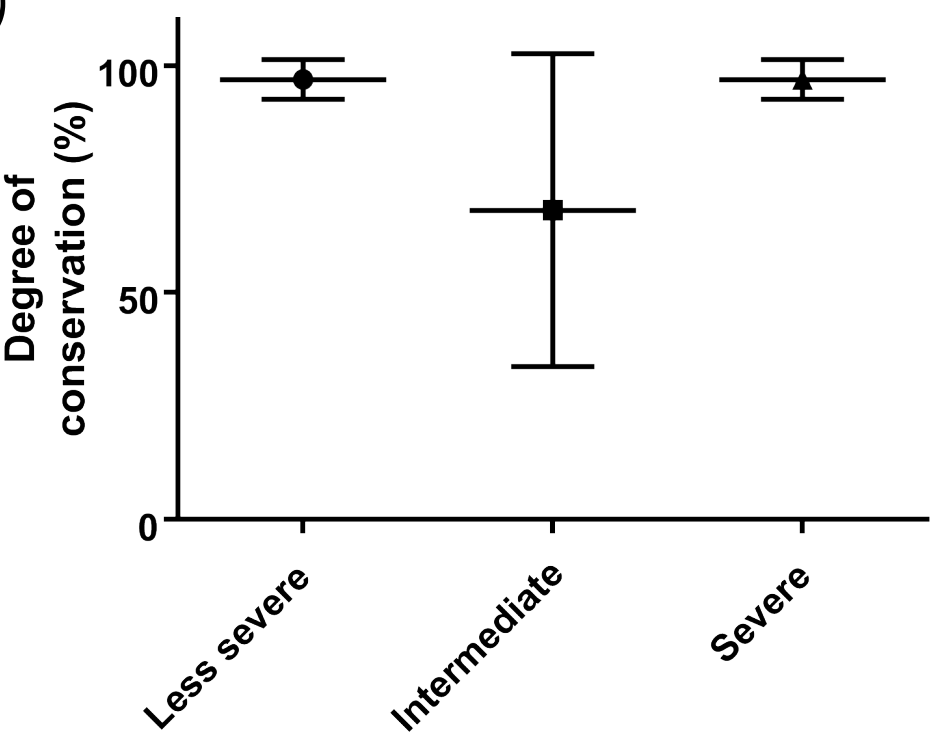

(b)

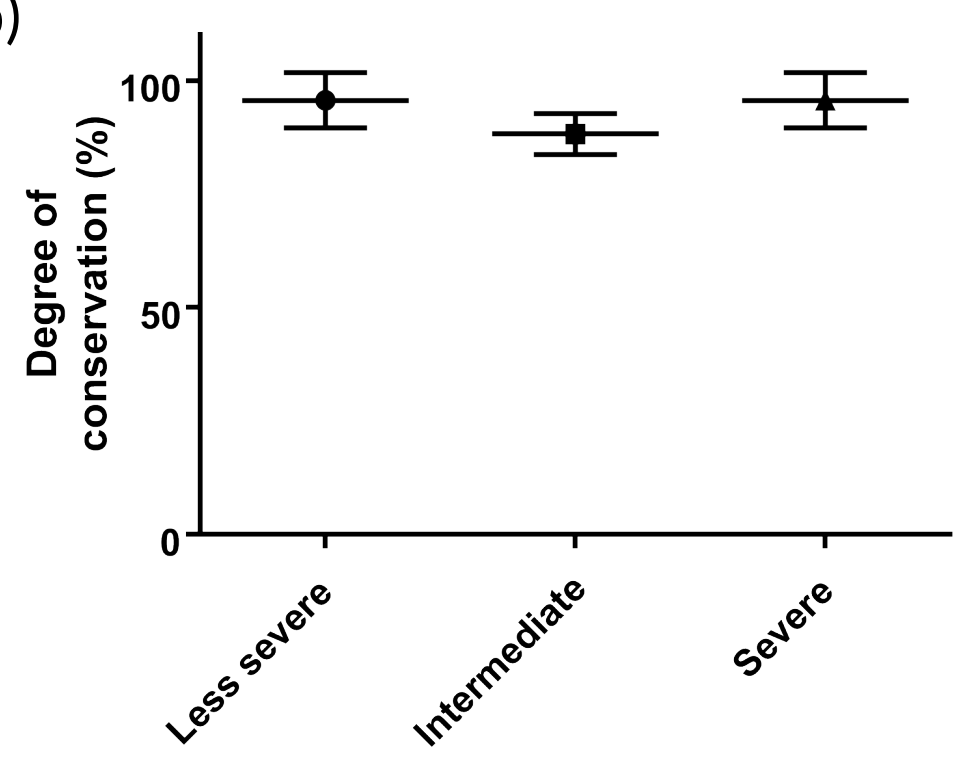

Supplementary figure S2: Comparison of the degree of conservation of the three groups of disease-associated variants. The comparison was based on (a) all species considered and (b) mammals. No significant difference between the groups was detected (one way ANOVA with Tukey's correction for multiple comparisons). 
Supplementary Table S2: Assignment of secondary structure in human TPI (PDB: 4POC) as determined by PyMol

\begin{tabular}{|c|c|}
\hline Residue Number & Secondary Structure \\
\hline 3-5 & Interconnecting Loop before 1 st $\beta$-sheet \\
\hline $6-11$ & 1st $\beta$-sheet \\
\hline $12-17$ & Interconnecting loop between 1st $\beta$-sheet and 1st $\alpha$-helix \\
\hline $18-30$ & 1st a-helix \\
\hline $31-36$ & Interconnecting loop between 1st $\alpha$-helix and 2 nd $\beta$-sheet \\
\hline $37-42$ & 2nd $\beta$-sheet \\
\hline $43-47$ & Interconnecting loop between 2nd $\beta$-sheet and 3rd a-helix \\
\hline 48-54 & 2nd a-helix \\
\hline $55-59$ & Interconnecting loop between 2 nd $a$-helix and $3 r d \beta$-sheet \\
\hline $60-63$ & 3rd $\beta$-sheet \\
\hline $64-79$ & Interconnecting loop between $3 r d \beta$-sheet and 3rd a-helix \\
\hline $80-86$ & 3rd a-helix \\
\hline 87-89 & Interconnecting loop between $3 r d a$-helix and 4 th $\beta$-sheet \\
\hline $90-93$ & 4th $\beta$-sheet \\
\hline $94-95$ & Interconnecting loop between 4 th $\beta$-sheet and 4 th a-helix \\
\hline $96-102$ & 4th a-helix \\
\hline $103-105$ & Interconnecting loop between 4th a-helix and 5th a-helix \\
\hline $106-119$ & 5th a-helix \\
\hline $120-121$ & Interconnecting loop between 5 th $\alpha$-helix and 5 th $\beta$-sheet \\
\hline $122-127$ & 5th $\beta$-sheet \\
\hline $128-130$ & Interconnecting loop between 5 th $\beta$-sheet and 6th a-helix \\
\hline $131-136$ & 6th a-helix \\
\hline 137 & Interconnecting loop between 6th $a$-helix and 7th a-helix \\
\hline $138-153$ & 7th a-helix \\
\hline $154-159$ & Interconnecting loop between 7th $\alpha$-helix and 6th $\beta$-sheet \\
\hline $160-164$ & 6th $\beta$-sheet \\
\hline $165-177$ & Interconnecting loop between 6th $\beta$-sheet and 8th a-helix \\
\hline $178-196$ & 8th a-helix \\
\hline 197 & Interconnecting loop between 8th and 9th a-helices \\
\hline $198-203$ & 9th a-helix \\
\hline $204-205$ & Interconnecting loop between 9th $\alpha$-helix and 7th $\beta$-sheet \\
\hline 206-208 & 7th $\beta$-sheet \\
\hline $209-216$ & Interconnecting loop between 7 th $\beta$-sheet and 10th a-helix \\
\hline $217-222$ & 10th a-helix \\
\hline $223-227$ & Interconnecting loop between 10th a-helix and 8th $\beta$-sheet \\
\hline $228-231$ & 8th $\beta$-sheet \\
\hline 232 & Interconnecting loop between 8th $\beta$-sheet and 11th a-helix \\
\hline $233-236$ & 11th a-helix \\
\hline 237 & Interconnecting loop between 11th and 12th a-helices \\
\hline $238-245$ & 12th a-helix \\
\hline $246-248$ & Final loop \\
\hline
\end{tabular}


Supplementary Table S3: Sequences used to construct sequence alignments.

\begin{tabular}{|c|c|}
\hline Species & Accession Number \\
\hline Homo Sapiens & P60174.3 \\
\hline Ailuropoda melanoleuca & XP_002922306.2 \\
\hline Aotus nancymaae & XP_012328257.1 \\
\hline Bison bison bison & XP_010843235.1 \\
\hline Bos taurus & NP_001013607.1 \\
\hline Canis lupus familiaris & NP_001183983.1 \\
\hline Cavia porcellus & XP_003463291.1 \\
\hline Ceratotherium simum simum & XP_004438751.1 \\
\hline Cercocebus atys & XP_011909761.1 \\
\hline Chinchilla lanigera & XP_005378895.1 \\
\hline Condylura cristata & XP_012588025.1 \\
\hline Dasypus novemcinctus & XP_004448557.1 \\
\hline Equus caballus & XP_001497522.2 \\
\hline Felis catus & XP_006933527.1 \\
\hline Fukomys damarensis & XP_010609974.1 \\
\hline Heterocephalus glaber & XP_004869515.1 \\
\hline Ictidomys tridecemlineatus & XP_005338375.1 \\
\hline Jaculus jaculus & XP_004668721.1 \\
\hline Loxodonta africana & XP_003410703.2 \\
\hline Macaca nemestrina & XP_011743949.1 \\
\hline Mesocricetus auratus & XP_005066069.1 \\
\hline Microcebus murinus & XP_012615900.1 \\
\hline Mus musculus & NP_033441.2 \\
\hline Mustela putorius furo & XP_004766701.1 \\
\hline Myotis brandtii & XP_005873734.1 \\
\hline Ochotona princeps & XP_004596449.1 \\
\hline Octodon degus & XP_004643583.1 \\
\hline Odobenus rosmarus divergens & XP_004413981.1 \\
\hline Orcinus orca & XP_004279116.1 \\
\hline Oryctolagus cuniculus & P00939.1 \\
\hline Otolemur garnettii & XP_012661797.1 \\
\hline Pan troglodytes & NP_001065250.1 \\
\hline Propithecus coquereli & XP_012493283.1 \\
\hline Pteropus vampyrus & XP_011364118.1 \\
\hline Rattus norvegicus & NP_075211.2 \\
\hline $\begin{array}{c}\text { Saimiri boliviensis } \\
\text { boliviensis }\end{array}$ & XP_010331175.1 \\
\hline Pongo abelii & NP_001126005.1 \\
\hline Sorex araneus & XP_004610688.1 \\
\hline Sus scrofa & NP_001032228.1 \\
\hline Tupaia chinensis & XP_006170851.1 \\
\hline Xenopus laevis & NP_001080476.1 \\
\hline Xenopus (Silurana) tropicalis & NP_001107706.1 \\
\hline Brachybacterium faecium DSM 4810 & YP_003154941.1 \\
\hline
\end{tabular}


Chlamydia trachomatis 434/Bu

Enterobacter aerogenes KCTC 2190

Escherichia coli 0104:H4 str. 2011C-3493

Listeria monocytogenes EGD-e

Mesorhizobium ciceri biovar biserrulae

WSM1271

Mycoplasma pneumoniae M129

Neisseria gonorrhoeae FA 1090

Rhodopirellula baltica SH 1

Streptococcus mutans UA159

Streptomyces coelicolor A3(2)

Thermanaerovibrio acidaminovoransDSM 6589

Anas platyrhynchos

Aquila chrysaetos canadensis

Corvus cornix cornix

Falco cherrug

Falco peregrinus

Haliaeetus leucocephalus]

Meleagris gallopavo

Pseudopodoces humilis

Pygoscelis adeliae

Gallus gallus

Esox lucius

Haplochromis burtoni

Ictalurus punctatus

Maylandia zebra

Oreochromis niloticus

Pundamilia nyererei

Xiphophorus maculatus

Apis mellifera

Athalia rosae

Bombus impatiens

Bombyx mori

Linepithema humile

Megachile rotundata

Microplitis demolitor

Monomorium pharaonis

Orussus abietinus

Papilio xuthus

Alligator mississippiensis

Alligator sinensis

Anolis carolinensis

Chelonia mydas

Chrysemys picta bellii

Pelodiscus sinensis

Python bivittatus
YP_001654656.1
YP_004591499.1
YP_006781500.1
NP_463876.1
YP_004144467.1

NP_110318.1

YP_207198.1

NP_867626.1

NP_721138.1

NP_624890.1

YP_003317406.1

XP_005016819.1

XP_011585873.1

XP_010394421.1

XP_005434378.1

XP_005235418.1

XP_010565882.1

XP_010716134.1

XP_005523884.1

XP_009327088.1 P00940.2

NP_001290932.1

XP_005951088.1

NP_001187543.1

$X P \_004569774.1$

XP_003452735.1

XP_005745225.1

NP_001273230.1

NP_001090623.1

XP_012257760.1

XP_012244746.1

NP_001119730.1

XP_012220627.1

XP_003700534.1

XP_008557282.1

XP_012533797.1

XP_012288390.1

XP_013179213.1

XP_006273455.1

XP_006037108.1

XP_003227154.1

XP_007069697.1

XP_005312065.1

XP_006124207.1

XP_007420484.1 
Thamnophis sirtalis

Arabidopsis thaliana

Bathycoccus prasinos

Erythranthe guttata

Glycine max

Medicago truncatula

Morus notabilis

Theobroma cacao Zea mays

Cicer arietinum

Jatropha curcas

Capronia epimyces CBS 606.96

Fomitiporia mediterranea MF3/22

Fusarium graminearum $\mathrm{PH}-1$

Nematocida parisii ERTm1

Neurospora crassa OR74A

Paracoccidioides brasiliensis Pb18

Pneumocystis murina B123

Pseudogymnoascus destructans20631-21

Schizosaccharomyces japonicus yFS275

Wickerhamomyces ciferrii

Cryptosporidium muris RN66

Fonticula alba

Gregarina niphandrodes

Leishmania infantum JPCM5

Plasmodium falciparum 3D7

Plasmodium reichenowi

Salpingoeca rosetta

Tetrahymena thermophila SB210

Thecamonas trahens ATCC 50062

Trypanosoma cruzi CL Brener
XP_013926209.1

NP_191104.1

XP_007510733.1

XP_012858305.1

NP_001237472.1

XP_013450029.1

XP_010111131.1

XP_007016406.1

NP_001147215.1

XP_004487007.1

XP_012075954.1

XP_007733361.1

XP_007261753.1

XP_011326337.1

XP_013059541.1

XP_959063.1

XP_010762134.1

XP_007874541.1

XP_012742655.1

XP_002175311.1

XP_011273813.1

XP_002142258.1

XP_009498316.1

XP_011129766.1

XP_001465915.1

XP_001348552.1

XP_012765443.1

XP_004990529.1

XP_001008794.2

XP_013760960.1

XP_818253.1 
Supplementary Table S4: Degree of conservation of the disease-associated residues

\begin{tabular}{ccc}
\hline Variant & $\begin{array}{c}\text { ScoreCons } \\
\text { All species }(\mathbf{n}=119)\end{array}$ & $\begin{array}{c}\text { ScoreCons - } \\
\text { Mammals only }(\mathbf{n}=\mathbf{4 0})\end{array}$ \\
\hline Ile170Val & $100 \%$ & $100 \%$ \\
Phe240Leu & $93.9 \%$ & $91.4 \%$ \\
Cys41Tyr & $43.8 \%$ & $85.0 \%$ \\
Val231Met & $92.5 \%$ & $91.4 \%$ \\
Phe240Ser & $93.9 \%$ & $91.4 \%$ \\
Glu104Asp & $100 \%$ & $100 \%$ \\
\hline
\end{tabular}

